\title{
Stoicka pneuma a Pawłowa koncepcja Ducha w Rz 8 \\ Cz.1: Argumentacja Rz 8 i przegląd badań nad stoicką pneumq u Pawła
}

The Stoic Pneuma and the Pauline Concept of Spirit in Rom 8

Part 1: The Argumentation of Rom 8 and the Survey

of Research on the Stoic Pneuma in Paul

\author{
KS. MARCIN KOWALSKI \\ Instytut Nauk Biblijnych, Katolicki Uniwersytet Lubelski Jana Pawła II \\ e-mail: xmkowal@gmail.com \\ ORCID: 0000-0002-8732-6868
}

\begin{abstract}
Summary: In the article the author poses a question on the nature and character of the Spirit's acting and indwelling in believers in Romans 8. To what extent can the Pauline concept of Spirit be associated with the stoic idea of pneuma which also dwells within humans, grants them knowledge and life? In order to answer this question, in the first part of the paper the author analyzes the semantic fields of Rom 5-8 and their convergence in Rom 8, with a special focus on the vocabulary of new life mediated by the Spirit. Subsequently, the rhetorical structure of Rom 8 is elucidated. At the end, the author presents a concise survey of the research on the interaction between the Pauline and the stoic idea of pneuma. The critical evaluation of the various scholarly works on the issue and the rhetorical dispositio of Rom 8 constitute a point of departure for a closer analysis of similarities and differences between Paul and the stoic pneumatology, which will be carried on in part two of the article.
\end{abstract}

Keywords: Spirit, Rom 8, rhetoric, stoicism, material pneuma, Pauline pneumatology SŁowa Klucze: Duch, Rz 8, retoryka, stoicyzm, materialna pneuma, Pawłowa pneumatologia

Dozdział ósmy w pełni zasługuje na miano wielkiego finału argumentacji Pawła w pierwszych ośmiu rozdziałach Listu do Rzymian ${ }^{1}$. Tu właśnie ze szczególną mocą wybrzmiewa zwycięstwo nowego życia w Chrystusie, do którego apostoł prowadził od początku swoich czytelników. Mimo że dwie części Rz 1-4 oraz 5-8 można traktować jako odrębne bloki tematyczne, w żadnym

1 Na temat szczytu, jaki osiąga tu historia Adama, zob. B. Witherington - D. Hyatt, Paul's Letter to the Romans. A Socio-Rhetorical Commentary (Grand Rapids, MI: Eerdmans 2004) 208. 
razie nie są one od siebie oderwane ${ }^{2}$. Zasadniczym elementem, który je spaja, jest temat Bożej sprawiedliwości, stanowiący motyw przewodni całego listu Pojawia się on w Rz 1,16-17, który powszechnie traktuje się jako tezę główną Rz 1-4, a nawet całego Listu do Rzymian. Paweł, wychodząc od pojęcia gniewu Bożego, tłumaczy, jak sprawiedliwość Boża ostatecznie znajduje sposób, aby zbawić każdego bez wyjątku, najpierw Żyda, a potem Greka" ${ }^{4}$ W Rz 3,25-26 apostoł, wprowadzając po długim oczekiwaniu postać Chrystusa, ukazuje na jak wielu poziomach dokonuje się usprawiedliwienie ludzkości w Tym, którego nazywa hilasterionem, przestrzenią i narzędziem przebłagania, łamiącym eschatologiczny wyrok potępienia, który zawisł nad całą ludzkością 5 .

2 Wśród egzegetów, którzy w Liście do Rzymian wyróżniają bloki 1-4 i 5-8, można wymienić: J.A. Fitzmyer, Romans. A New Translation with Introduction and Commentary (AB 33; New York: Doubleday 1993) ix, 479; W. Hendriksen, Romans. Exposition of Paul's Epistle to the Romans (New Testament Commentary; Grand Rapids: Baker Book House 1981) 244; C.K. Barrett, The Epistle to the Romans (BNTC 6; London: Hendrickson ${ }^{2} 1991$ ) 145; D.J. Moo, The Epistle to the Romans (NICNT; Grand Rapids, MI: Eerdmans 1996) 290-295; R. Jewett - R.D. Kotansky, Romans. A Commentary on the Book of Romans (Hermeneia; Minneapolis: Fortress Press 2007) 345-348; R.H. Mounce, Romans (NAC 27; Nashville, TN: Broadman \& Holman 1995) 173; C.E.B. Cranfield, A Critical and Exegetical Commentary on the Epistle to the Romans. Introduction and Commentary on Romans I-VIII (ICC; Edinburgh: T \& T Clark 2004) 252-254; T.R. Schreiner, Romans (BECNT 6; Grand Rapids, MI: Baker Books 1998) 245-250. Niektórzy włączają rozdział 5 . do części $1-4$, co potwierdza jedynie związek leksykalny i logiczny istniejący między nimi: F.L. Godet, Commentary on Romans (Grand Rapids, MI: Kregel 1977) 59, 231; W. Sanday - A.C. Headlam, A critical and Exegetical Commentary on the Epistle of the Romans (ICC; New York 1897) xlvii-xlix; L. Morris, The Epistle to the Romans (The Pillar New Testament Commentary; Leicester, England - Grand Rapids, MI: Apollos; Eerdmans 1988) 243; J. Murray, The Epistle to the Romans (NICNT; Grand Rapids, MI: Eerdmans 1959) I, 211-212; O. Kuss, Der Römerbrief (Regensburg: Pustet 1963-1978) I, 199; M. Wolter, Rechtfertigung und zukünftiges Heil. Untersuchungen zu Röm 5,1-11 (BZNW 43; Berlin - New York: De Gruyter 1978) 214-216; U. Wilckens, Der Brief an die Römer (EKKNT; Neukirchen-Vluyn - Zurich: Neukirchener Verlag; Benziger 1978-1981) I, 286-287; P.J. Achtemeier, Romans (Interpretation; Atlanta: John Knox Press 1985) 89; J.D.G. Dunn, Romans 1-8 (WBC 38A; Dallas, TX: Word Books 1988) 301-303.

Więcej na temat rozwinięcia tematów Rz 1-4 w Rz 5, zob. w: N.A. Dahl, Studies in Paul. Theology for the Early Christian Mission (Minneapolis: Augsburg 1977) 88-90; U. Luz, „Zum Aufbau von Röm 1-8", ThZ 25 (1969) 161-181, zwł. 178; N. Elliott, The Rhetoric of Romans. Augmentative Constraint and Strategy and Paul's Dialogue with Judaism (JSNTSup 45; Sheffield: Sheffield Academic Press 1990) 226; P.M. McDonald, „Romans 5:1-11 as a Rhetorical Bridge", JSNT 40 (1990) 84-87; J.-N. Aletti, God's Justice in Romans. Keys for Interpretating the Epistle to the Romans (SubBi 37; Rome: Gregorian \& Biblical Press 2010) 44-56.

3 Sugeruje to tytuł publikacji oraz analizy prowadzone w: Aletti, God's Justice in Romans. Zob. także M. Kowalski, „Problem Bożej sprawiedliwości w świetle Listu do Rzymian”, VV 26 (2014) 95-126.

4 Por. M. Kowalski, „Apokaliptyczny gniew Boga i jego miejsce w Ewangelii Pawła (Rz 1,1832)", VV 33 (2018) 203-249.

5 Por. M. Kowalski, „Bóg ustanowił Chrystusa nowym miejscem przebłagania. Pawłowa wizja usprawiedliwienia według Rz 3,25-26", Głoszenie odpuszczenia grzechów w imię Jezusa (Łk 24,47) (red. K. Mielcarek) (Lublin: Wydawnictwo KUL 2015) 163-190. 
Bez zrozumienia argumentacji Pawła w Rz 1-4 trudno pojąć pasję, z jaką w Rz 6-7 opisuje on niemożność powrotu do starego życia naznaczonego grzechem i Prawem. Usprawiedliwienie wprowadza równocześnie temat nowego życia, dostępnego przez wiarę w Chrystusa, które apostoł opisuje w rozdziałach Rz 5-8. Paweł obrazuje tu z jednej strony absolutne zwycięstwo łaski Chrystusa, z drugiej zaś - ciągłe zmaganie wierzących o to, aby to zwycięstwo objęło całą ich egzystencję ${ }^{6}$. Nowe życie, które może być porównane do ziarna gorczycy, natrafia wciąż na przeszkody w postaci grzechu, niewoli ludzkiego samousprawiedliwienia i Prawa oraz zepsucia tego świata. W każdej z tych trzech sytuacji z pomocą przychodzi wierzącemu Duch, który wyzwala z niewoli grzechu i Prawa oraz zamienia krzyk rozpaczy stworzenia poddanego przemijaniu i marności w modlitwę i bóle, w których rodzi się nowe życie. Duch nie jest dodatkiem, ale niezbędnym ogniwem nowego życia, co doskonale pozwalają dostrzec przyłożone do Rz 5-8 modele społeczne i antropologiczno-kulturowe. Dzięki nim możemy w Bogu dostrzec Ojca, patrona i benefaktora ludzkości, zaś w Duchu - koniecznego pośrednika (brokera) Bożej łaski, bez którego pozostaje ona dla ludzkości nieosiągalna ${ }^{7}$.

Model socjologiczny, choć pomocny w zarysowaniu roli Ducha jako należącego do Bożej rodziny i wprowadzającego do niej wierzących, pozostawia jednak jeszcze wiele pytań bez odpowiedzi. Jak Paweł mógł pojmować naturę Ducha? Na czym polega Jego rola, działanie i zamieszkiwanie w wierzących, które apostoł opisuje w Rz 8? W rozdziale tym znajdujemy wiele uderzających podobieństw pomiędzy Pawłem a popularnymi poglądami stoickimi, według których duch (pneuma) także przebywał w człowieku, obdarzając go wiedzą i życiem. Jak zwykle w takich przypadkach zestawianie ze sobą środowiska grecko-rzymskiego i myśli apostoła może okazać się niezwykle owocne nie tylko w szukaniu paraleli, ale także różnic między nimi ${ }^{8}$. A zatem, w jakim stopniu myśl Pawła można powiązać z popularną myślą stoicką? Na pytania te będziemy chcieli odpowiedzieć w niniejszym opracowaniu, które stanowi zwieńczenie serii artykułów autora na temat usprawiedliwienia, daru nowego życia i roli Ducha w Rz 1-8. Obecna praca dzielić się będzie na dwie części. W pierwszej rozpoczniemy od przeglądu pól semantycznych, które pojawiają się w Rz 5-8, a ogniskują w Rz 8, po czym zaprezentujemy szczegółowo strukturę retoryczną

6 Por. M. Kowalski, „Nowe życie jak ziarno gorczycy. Spójność argumentacji retorycznej Pawła w Rz 5-8", BibAn 7/4 (2017) 459-485.

7 Por. M. Kowalski, „God the Benefactor and His Human Clients in Rom. 5-8”, BibAn 8/1 (2018) 47-69; M. Kowalski, „The Brokerage of the Spirit in Rom 8”, CBQ 80/4 (2018) (oddany do druku).

8 Zwyczajem jest przywoływanie w tym kontekście autora, który ukuł termin ,paralelomania”, ostrzegając przed jednostronnym i przesadnym eksploatowaniem podobieństw między środowiskami i tekstami bez dostatecznej podstawy historyczno-literackiej. Zob. S. Sandmel, „Parallelomania”, JBL 81/1 (1962) 1-13. 
rozdziału ósmego. Następnie przejdziemy do zwięzłego przeglądu badań wiążących myśl Pawła z koncepcjami stoickimi. W części drugiej niniejszego artykułu porównamy koncepcje stoickie z Pawłową myślą na temat Ducha w Rz 8, aby dostrzec możliwe punkty wspólne oraz oryginalność Pawłowej pneumatologii.

\section{Struktura argumentacji Pawła w Rz 8}

Argumentacji Pawła w Rz 8 przyjrzymy się w dwóch krokach. Pierwszy wiązać się będzie $\mathrm{z}$ tematami, które pojawiają się $\mathrm{w}$ interesującym nas rozdziale na tle całej jednostki Rz 5-8. Drugi krokiem będzie próba spojrzenia na różnorodne pola semantyczne w Rz 8 w perspektywie dspositio retorycznej tegoż rozdziału. Jak się o tym przekonany, to właśnie ona pozwala nam uporządkować mnogość wątków w logiczną argumentację Pawła w rozdziale wieńczącym Rz 5-8.

\subsection{Tematy pojawiające się w Rz 8 na tle jednostki Rz 5-8}

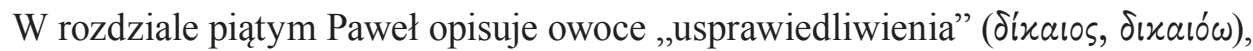
które przynosi Chrystus. Nowe życie wierzących cechuje „nadzieja” ( $\left.\dot{\varepsilon} \lambda \pi i \varsigma^{\prime}\right)$

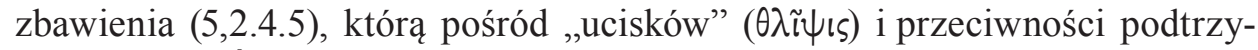
muje „Duch Święty” ( $\pi \nu \varepsilon \tilde{\mu} \mu \alpha$ ă $\gamma ı v)(\mathrm{Rz} 5,5)^{9}$. Pojawiające się w Rz 5,6-11

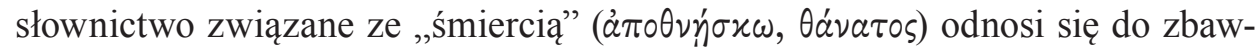
czej ofiary Chrystusa, która przynosi pojednanie i zbawienie ${ }^{10}$. W Rz 5,10 po

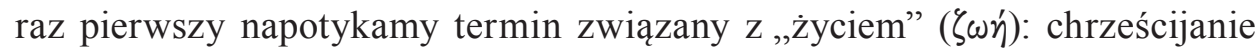
pojednani z Bogiem przez śmierć Pana z pewnością dostąpią zbawienia „przez

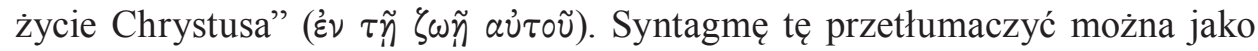
odniesienie do zmartwychwstania ${ }^{11}$. Nowe życie to nic innego jak uczestniczenie w zmartwychwstałym życiu Pana.

Pod koniec rozdziału piątego, w. 12-21, Paweł wprowadza porównanie między Adamem i Chrystusem, mające zobrazować obfitość łaski wkraczającej w ludzki świat w tym drugim. Tak jak przez ,jednego” (عĩ ) ludzkość pogrążyła

9 Schreiner wyróżnia w Rz 5,1-11 słownictwo związane z nadzieją, która - według niego - stanowi temat główny sekcji. Por. Schreiner, Romans 245. Zob. także Dunn, Romans, 1-8, 246; Moo, The Epistle to the Romans, 297.

10 Zob. Rz 5,6.7.8.10. Por. także Fitzmyer, Romans 394.

11 Por. Fitzmyer, Romans, 401; Schreiner, Romans, 264; Barrett, The Epistle to the Romans, 100; Dunn, Romans 1-8, 260-261. Moo, The Epistle to the Romans, 312 podkreśla uczestniczenie wierzących w życiu Chrystusa, które ocali ich w czasie sądu ostatecznego. Jewett - Kotansky, Romans, 367 twierdzą, że chodzi o życie w Chrystusie już dziś pośród cierpień, słabości i prześladowań, które zapowiadają przyszłą chwałę. 


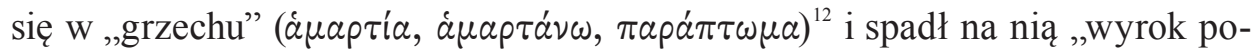

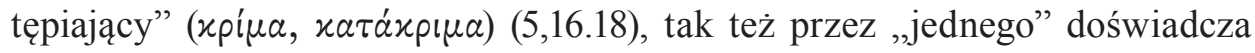

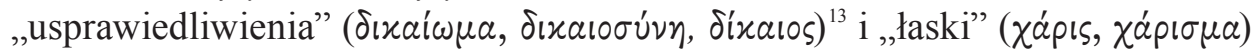
(5,15.20.21). Pojawiające się w tej części słownictwo związane z „grzechem”,

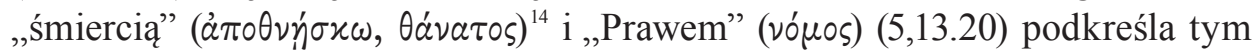
bardziej triumf Chrystusa, który złamał ich potęgę, otwierając wierzącym drogę do życia ${ }^{15}$. Słownictwo związane z „życiem” ( $\left(\omega \eta \eta^{\prime}\right)$, które tu także występuje, oznacza: zmartwychwstałe życie Chrystusa, w którym wierzący trwają, aby pewnego dnia dostąpić królowania w chwale $(\mathrm{Rz} 5,17)^{16}$; nowe życie, które jest darem dla usprawiedliwionych $(5,18)$; oraz życie wieczne $(5,21)^{17}$. Ostatecznie tematy „śmierci”, „grzechu”, „Prawa” i „potępienia” w rozdziale piątym są całkowicie podporządkowane tematom „,aski”, „pojednania”, „usprawiedliwienia”, które przynosi „,jeden”, Chrystus. Nowe życie wydaje się tu niczym niezagrożone.

Sytuacja ta zmienia się w rozdziale szóstym. Paweł przechodzi od refleksji nad darem nowego życia przyniesionego przez Chrystusa do konkretnej aplikacji w egzystencji chrześcijanina. W Rz 6,1-14 na plan pierwszy wysuwa się temat

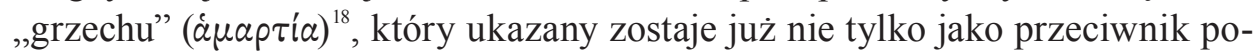
konany przez Chrystusa (Rz 5,1-21), ale jako rzeczywistość absolutnie niekompatybilna z życiem usprawiedliwionych. Chrześcijanie zanurzeni przez „chrzest”

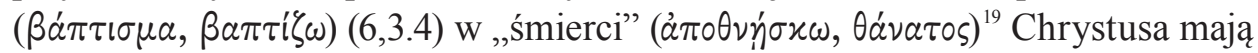
umrzeć dla „grzechu”, aby zmartwychwstać razem z Panem. Nowe „życie” ( $\zeta \alpha \omega, \sigma u \zeta \dot{\alpha} \omega, \zeta \omega \eta \dot{)}$ ), którego słownictwo często, bo aż siedem razy, pojawia się w w. 1-14, oznacza: życie w Chrystusie, które wyklucza życie w grzechu $(6,2)$; nową rzeczywistość, w którą wierzący wkracza przez chrzest $(6,4)^{20}$; zapowiadane życie zmartwychwstania $(6,8)^{21}$; życie naśladujące Chrystusa w jego nowej

$12 \quad$ Zob. Rz 5,12.13.14.16.19.20.21.

13 Zob. Rz 5, 16.17.18.19.21.

$14 \quad$ Zob. Rz 5,12.14.15.17.21.

15 Por. Fitzmyer, Romans, 418-419.

16 Por. Dunn, Romans 1-8, 282; Jewett - Kotansky, Romans, 384; Cranfield, A Critical and Exegetical Commentary on the Epistle to the Romans 287.

17 Dunn, Romans 1-8, 287 traktuje je jako ekwiwalent życia sprawiedliwości z Rz 5,18. Fitzmyer, Romans, 422 i Schreiner, Romans, 296 mówią o życiu w przyszłym świecie, życiu zmartwychwstania.

$18 \quad$ Zob. Rz 6,1.2.6.7.10.11.12.13.14.

19 Zob. Rz 6,2.3.4.5.7.8.9.10.13.

20 Fitzmyer, Romans, 434 podkreśla tu podobieństwo do Chrystusa, życie Jego życiem, życie nowego stworzenia. Zob. także Jewett - Kotansky, Romans, 399. Cranfield, A Critical and Exegetical Commentary on the Epistle to the Romans, 304-305 mówi o życiu związanym $\mathrm{z}$ eschatologiczną nadzieją i uczestniczeniem już w ostatecznej odnowie świata. Moo, The Epistle to the Romans, 366 za element wyróżniający nowe życie w 6,4 uznaje Ducha.

21 Wbrew narzucającej się eschatologicznej interpretacji czasownika $\sigma u \zeta a ́ \omega \omega$ Jewett - Kotansky, Romans, 406 proponują czytać go jako odniesienie do życia dzielonego z Chrystusem od 
relacji z Ojcem, do którego zaproszeni są wierzący $(6,10.11)^{22}$; czy wreszcie życie, w którym wierzący już dziś antycypują zmartwychwstanie $(6,13)$.

W drugiej części rozdziału szóstego $(6,15-23)$ obraz nowego życia chrześcijanina ulega znacznej dramatyzacji. Słownictwo stricte związane z, życiem” ( $(\omega \eta ́)$ pojawia się tu tylko dwa razy. Oznacza ono życie wieczne, które jest owocem uświęcenia i oddania się na służbę Bożą $(6,22)$ oraz ostateczną zapłatą, jaką człowiek otrzymuje do Boga $(6,23)^{23}$. Życie to jest w chrześcijaninie zagrożone

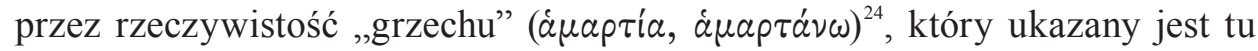

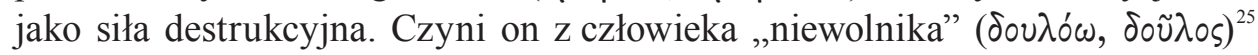

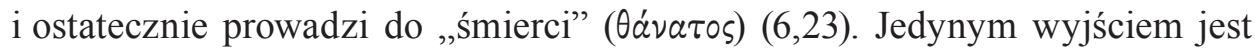

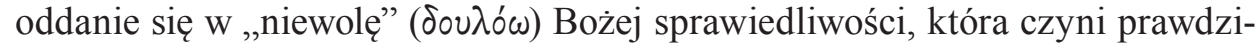

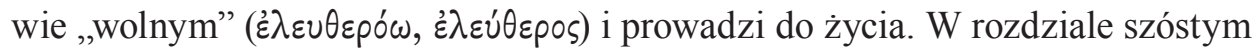
wraz z często pojawiającymi się imperatywami Paweł coraz wyraźniej akcentuje odpowiedzialność wierzących za dar nowego życia. Wymaga ono śmierci dla grzechu, postępowania w nowości życia, naśladowania życia Chrystusa, oddania się Bogu i jego sprawiedliwości oraz wysiłku uświęcenia.

Czy jednak człowiek o własnych siłach zdolny jest do podjęcia takiego wysiłku? Słownictwo w rozdziale siódmym ukazuje pogłębiający się dramat zmagania o nowe życie. W rozdziale tym dominuje słownictwo związane z „Prawem”

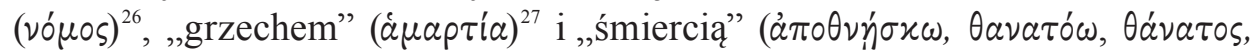
$\dot{a} \pi \circ x \tau \varepsilon^{\prime}(\nu \omega)^{28}$. W Rz 7,1-6 człowiek pozostaje pod władzą Prawa, a jedynym spo-

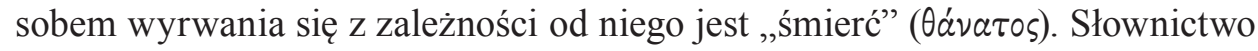
związane z ,życiem” ( $\zeta a ́ \omega)$ w tej części nie odnosi się stricte do nowego życia, lecz opisuje życie doczesne człowieka poddanego Prawu, które przypomina poddanie żony mężowi (7,1-3).

W dalszej części, w Rz 7,7-25, dominuje wciąż temat Prawa (pojawia się aż 15 razy). Choć jest ono ukazane jako dobre i święte, wraz ze wszystkimi

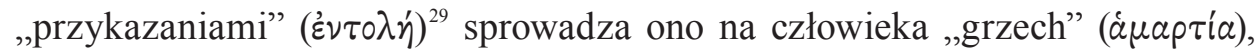

nawrócenia aż do eschatonu. Zob. także Moo, The Epistle to the Romans, 377; Cranfield, A Critical and Exegetical Commentary on the Epistle to the Romans, 312.

22 Por. Fitzmyer, Romans, 438. Idea życia dla Boga charakteryzująca w judaizmie męczenników i tych, którzy osiągnęli wyższy stopień kontemplatywnej doskonałości, staje się otwarta dla wszystkich chrześcijan. Por. Dunn, Romans 1-8, 324.

23 Życie wieczne jako zapłata od Boga pozostaje mimo wszystko bezinteresownym, przekraczającym ludzkie zasługi darem Bożej miłości. Por. Fitzmyer, Romans, 452; Barrett, The Epistle to the Romans, 125; Jewett - Kotansky, Romans, 426.

24 Zob. Rz 6, 16.17.18.20.22.23.

25 Zob. Rz 6,16.17.18.19.20.22.

26 Zob. Rz 7,1.2.3.4.5.6.7.8.9.12.14.16.21.22.23.25.

27 Zob. Rz 7,5.7.8.9.11.13.14.17.20.23.25.

28 Zob. $\mathrm{Rz}$ 7,2.3.4.5.9.10.13.24.

29 Zob. Rz 7,8.9.12.13. 


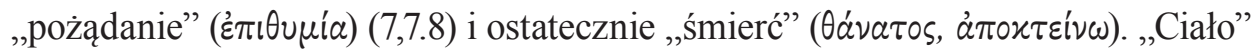
$(\sigma \alpha ́ \rho \xi, \sigma \alpha ́ \rho x เ v \circ \varsigma)^{30}$ człowieka zostaje przez apostoła przedstawione jako siedlisko grzechu. Słownictwo odnoszące się do „życia”, które pojawia się w tej części, opisuje życie, jakie prowadził podmiot przed pojawieniem się Prawa $(7,9)$, życie grzechu odżywającego w człowieku $(7,9)$ czy wreszcie przykazanie, które mając służyć życiu, wyzwoliło w człowieku siłę śmierci $(7,10)^{31}$. Jak widzimy, W rozdziale siódmym praktycznie znika temat nowego życia, zduszonego przez działanie „Prawa”, „grzechu” i ,śmierci”. Wydaje się, że człowiek o własnych siłach nie jest w stanie ustrzec $\mathrm{w}$ sobie daru nowego życia.

Rozdział ósmy przynosi zwrot w opisywanym przez Pawła dramacie, który ilustruje nowe pojawiające się w nim słownictwo. Tu właśnie na plan pierwszy wysuwa się Duch/duch ( $\pi \nu \varepsilon u \tilde{\mu \alpha}$ ), który ogółem pojawi się w Rz 8 aż dwadzieścia jeden razy, z czego dwadzieścia razy będzie to odniesienie do Ducha Świętego ${ }^{32}$. Wcześniej Paweł wspominał go tylko dwa razy: jako pośrednika Bożej miłości (Rz 5,5) oraz nowego życia $(7,6)$. Zarysowane wcześniej idee apostoł rozwija w Rz 8. Duch jawi się tu jako dawca nowego prawa, które wyzwala z mocy grzechu $(8,2)$, Ten, który uzdalnia wierzących do wypełnienia Prawa $(8,4)$ oraz daje życie i pokój (8,5-6). Duch mieszka w ochrzczonych i odpowiada za ich wskrzeszenie z martwych (8,9-11), jest aktywnie obecny przy ich usynowieniu (8,13-16) oraz wstawia się za nimi i za całym stworzeniem $(8,23.26-27)$.

W Rz 8,1-17 wciąż jeszcze mamy do czynienia z „Prawem” (vópos), ale nie ma już ono negatywnych konotacji z rozdział siódmego, a nawet mówi się tu o ,prawie Ducha” $(8,2)$ czy o ,prawie Bożym” $(8,7)^{33}$. „Ciało” $(\sigma \alpha ́ p \xi, \sigma \tilde{\omega} \mu \alpha)$, znane z rozdziału siódmego jako siedlisko grzechu, teraz przedstawione zostaje jako forma bytowania Syna $(8,3)$ czy też sposób życia na wzór tego świata, wrogi

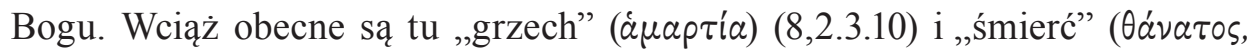

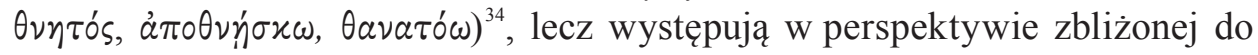
rozdziału piątego, jako rzeczywistości pokonane przez Chrystusa. Znaczącemu

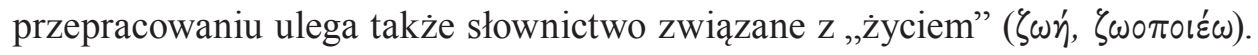
W Rz 5 pojawia się ono jako dar Chrystusa (Rz 5). Dalej, w szóstym rozdziale Paweł ukazuje je jako absolutnie niedające się pogodzić z grzechem, zaś w Rz 7 jawi się jako nieosiągalne dla człowieka, choć obiecane przez Prawo. W Rz 8 Jest ono przedstawione jako dar Ducha, który daje wolność i zapowiada

Zob. Rz 7,4.5.18.24.25.

Por. Kpł 18,5 cytowane przez Pawła w Ga 3,12; Rz 10,5.

32 Zob. Rz 8,2.4.5.6.9.11.13.14.15.16.23.26.27. Por. Moo, The Epistle to the Romans, 468. Dunn, Romans 1-8, 301 w swoich zestawieniach słownictwa pomija zupełnie Ducha.

33 Na temat syntagmy ,prawo Ducha”, zob. Dunn, Romans 1-8, 416-418; Moo, The Epistle to the Romans, 473-476; Cranfield, A Critical and Exegetical Commentary on the Epistle to the Romans, 473-477.

$34 \quad$ Zob. Rz 8,2.6.13.34.38. 
zmartwychwstanie $(8,2.10)^{35}$, jako owoc myślenia według Ducha $(8,6)^{36}$ czy zmartwychwstanie dla tych, którzy mają w sobie Ducha Świętego $(8,11)$. Apostoł stawia przed oczyma wierzących dwie drogi: żyć według ciała, na sposób światowy $(8,12.13)$, albo żyć na wieki poprzez Ducha, uśmiercając popędy ciała $(8,13)$. Darem Ducha jest także usprawiedliwienie $(8,4.10 .30 .33)$, które w Rz 5 Paweł przedstawił jako dar Jezusa ${ }^{37}$.

W dalszej części Rz 8,18-30 sytuacja nowego życia w wierzących ulega niespodziewanemu, dramatycznemu zwrotowi. Paweł wraca, co prawda, do tematu

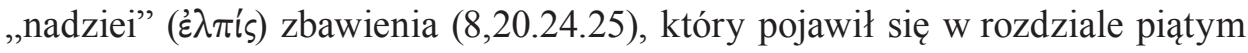
(5,2.4.5), jednak wprowadza równocześnie obraz „stworzenia” ( $\varkappa \tau i \sigma \varsigma \varsigma)$, które ,jęczy" ( $\sigma \tau \varepsilon \nu a ́ \zeta \omega)$ i wzdycha w bólach, oczekując na objawienie się synów Bożych $(8,19)$. Z pomocą przychodzi mu „Duch”, który także w tej części wspominany jest często (4 razy) $(8,23.26 .27)$. Słownictwo związane stricte $\mathrm{z}$ „życiem” nie pojawia się tu ani raz. Nie da się oprzeć wrażeniu, że napotykamy tu kolejną przeszkodę dla nowego życia w chrześcijaninie, o której sam układ tematów nie może nam wiele powiedzieć.

Tym bardziej zaskakującym jest następująca bezpośrednio po Rz 8,18-30 część finalna, Rz 8,31-39. Nie ma w niej wyraźnie dominującego wątku tematycznego. Najczęściej (3 razy) pojawia się słownictwo związane ze „śmiercią”

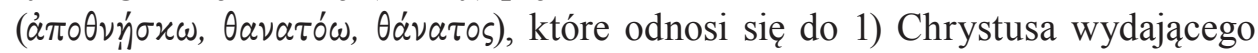
się na śmierć za zbawienie swoich $(8,33), 2)$ chrześcijan zabijanych ze względu na Jezusa $(8,36)$, czy 3$)$ śmierci, która nie jest w stanie oddzielić wierzących od Pana (8,38). „Życie” ( $(\omega \eta)$ ), wspominane w Rz 8,31-39 tylko raz, oznacza doczesność, która także nie może wyrwać wierzących z mocy Zbawiciela $(8,38)^{38}$. Część Rz 8,31-39 to w istocie hymn pochwalny na cześć Bożej miłości, w której objęciach bezpiecznie spoczywają chrześcijanie. To także wymowny, bo zamykający całość Rz 5-8, obraz triumfu nowego życia w nas.

Widać wyraźnie, że w Rz 8 Paweł podejmuje tematy, które pojawiały się w całej jednostce Rz 5-8. Według Douglasa Moo rozdział ten na podobieństwo kuli śnieżnej, tocząc się w dól, zbiera wszystkie wątki, które pojawiły się wcześniej ${ }^{39}$. Jean-Noël Aletti z kolei słusznie dostrzega korespondencję pomiędzy

35 Por. Fitzmyer, Romans, 491; Cranfield, A Critical and Exegetical Commentary on the Epistle to the Romans, 390;

36 Życie i pokój, będące owocem myślenia według Ducha można traktować jako pełnię eschatologicznych darów. Por. Dunn, Romans 1-8, 426

37 Zob. 5,1.7.9.16.17.18.19.21.

38 Życie i śmierć formują tu meryzm oznaczający wszelkiego rodzaju próby i cierpienia. Por. Fitzmyer, Romans, 534-535; Cranfield, A Critical and Exegetical Commentary on the Epistle to the Romans, 441; Moo, The Epistle to the Romans, 544. Dunn, Romans 1-8, 507, mówi o napięciu w ziemskim życiu, w którym człowiek nie osiągnął jeszcze zbawienia.

39 Zob. Moo, The Epistle to the Romans, 470. 
tematami występującymi w rozdziałach piątym i ósmym. Sekcja 8,31-39 wraz z wątkami śmierci Chrystusa, łaski i prześladowań odpowiada Rz 5,1-11, zaś Rz 5,12-21 znajduje swój odpowiednik w Rz 8,1-30 ${ }^{40}$. Jak wyjaśnić te korespondencje, a równocześnie pogodzić ze sobą różne tematy i rejestry, w których Paweł opisuje Ducha i dar nowego życia w Rz 8? Skąd bierze się nagła zmiana tonu w opisie stworzenia wciąż jęczącego w bólach rodzenia w Rz 8,18-30, skoro towarzyszy mu ten sam Duch, który decyduje o wolności dzieci Bożych w Rz 8,1-17? Na pytania te odpowiemy, analizując dispostitio retoryczną Rz 8.

\subsection{Struktura retoryczna $R z 8$}

Idąc za monografiami Alettiego i Gieniusza, Rz 8 podzielić można na trzy części: w. 1-17, w. 18-30 oraz w. 31-39 ${ }^{41}$. Paweł rozpoczyna od tezy (subpropositio), którą odnaleźć możemy w Rz 8,1-2

40 Zob. J.-N. Aletti, „Romans 5-8. The Arrangement and Its Theological Relevance”, New Approaches for Interpreting the Letters of Saint Paul. Collected Essays : Rhetoric, Soteriology, Christology and Ecclesiology (SubBi 43; Roma: Gregorian \& Biblical Press 2012) 65n12, 72. Zob. także J.H. Lee, Paul's Gospel in Romans. A Discourse Analysis of Rom. 1:16-8:39 (Linguistic Biblical Studies 3; Leiden - Boston: Brill 2010) 309; Moo, The Epistle to the Romans, 292-295; C.D. Myers, „Chiastic Inversion in the Argument of Romans 3-8”, NovT 35/1 (1993) 41-43.

41 Por. J.-N. Aletti, „Romans 8. The Incarnation and Its Redemptive Impact”, New Approaches for Interpreting the Letters of Saint Paul. Collected Essays: Rhetoric, Soteriology, Christology and Ecclesiology (SubBi 43; Roma: Gregorian \& Biblical Press 2012) 112; A. Gieniusz, Romans 8,18-30. Suffering Does Not Thwart the Future Glory (USFSJH 9; Atlanta, GA: Scholars 1999) 57-83. Zob. także innych, którzy podobnie dzielą Rz 8: E. Lohse, „Zur Analyse und Interpretation von Röm 8,1-17", The Law of the Spirit in Rom 7 and 8 (red. J.-M. Cambier - B. Langley) (Rome: St Paul's Abbey 1976) 129-146; R.J. Dillon, „The Spirit as Taskmaster and Troublemaker in Romans 8", CBQ 60/4 (1998) 682-702; Schreiner, Romans, 395; Jewett - Kotansky, Romans, 475-534; C. Breytenbach, „Creation and the revelation of God's children. Liberation of enslaved bodies”, In die Skriflig 47/2 (2013) 1-7; Lee, Paul's Gospel in Romans, 383-430. Cezurę w w. 18 widzą Cranfield, A Critical and Exegetical Commentary on the Epistle to the Romans, 370-371 (Rz 8,1-11; 8,12-16; 8,17-30; 8,31-39); Moo, The Epistle to the Romans, 468-480 (Rz 8,1-13; 8,14-17; 8,18-30; 8,31-39). Cezurę w w. 12 i 14 stawiają natomiast: I. de La Potterie, „Le chrétien conduit par l'Esprit dans son cheminement eschatologique (Rom 8,14)”, The Law of the Spirit in Rom 7 and 8 (red. J.-M. Cambier - B. Langley) (Rome: St Paul's Abbey 1976) 229 (konstrukcja chiastyczna, A - w. 14-18, B - w. 19-25, A' - w. 26-30); Fitzmyer, Romans, 405, 497 (8,1-13 i 8,14-39); Barrett, The Epistle to the Romans, 145 (Rz 8,1-11; 8,12-30 i 8,31-39); T. Engberg-Pedersen, ,The Material Spirit. Cosmology and Ethics in Paul”, NTS 55/2 (2009) 194.

42 Por. Aletti, „Romans 8”, 114-115; Gieniusz, Romans 8,18-30, 45; C. Grappe, „Qui me délivrera de ce corps de mort? l'esprit de vie! Romains 7,24 et 8,2 comme éléments de typologie adamique", Bib 83/4 (2002) 491; J.-B. Matand Bulembat, Noyau et enjeux de l'eschatologie paulinienne. De l'apocalyptique juive et de l'eschatologie hellénistique dans quelques argumentations de l'apôtre Paul. Etude rhétorico-exégétique de 1 Co 15, 35-58; 2 Co 5, 1-10 et Rm 8, 18-30 (WUNT II/ 84; Berlin - New York: De Gruyter 1997) 189. Na temat retorycznej dispositio 
8,1-2: subpropositio: Dla tych, którzy są w Chrystusie nie ma potępienia

ratio: Prawo Ducha wyzwala spod prawa grzechu i śmierci

8,3-4: Argument 1: wypełnienie Prawa w życiu wierzących dzięki dziełu Chrystusa

8,5-13: Argument 2: nowe życie wierzących z Ducha

w. 5-8: prowadzeni przez Ducha, nie przez ciało

w. 9-11: należący do Chrystusa

w. 12-13: zdolni panować nad „popędami ciała”

8,14-17: transitio: dar usynowienia - Duch kształtujący nową relację z Bogiem

i Chrystusem, motywacja do życia etycznego

Fraza „Dla tych, którzy są w Chrystusie Jezusie nie ma już potępienia” prowadzić będzie myśl apostoła w Rz 8,1-17 ${ }^{43}$. Wers 2. spełnia funkcję ratio, uzasadnienia dla wcześniejszego twierdzenia. Duch, dawca życia, wyzwolił wierzących spod prawa grzechu i śmierci, zdejmując z nich potępiający wyrok. Pierwszy argument, który apostoł podaje dla poparcia swojej tezy, ma charakter chrystologiczny: Bóg, posyłając swego Syna, wydał w nim wyrok potępiający grzech, przez co wypełniły się nakazy Prawa $(8,3)^{44}$. Warunkiem, dzięki któremu wierzący doświadczają nowej rzeczywistości, jest postępowanie według Ducha $(8,4)$. Tylko ci, którzy dają się prowadzić Duchowi, doświadczają wolności od potępiającego wyroku Prawa. To, co zostało wypracowane przez Chrystusa, staje się osiągalne w życiu wierzących dzięki Duchowi ${ }^{45}$.

Duch jest łącznikiem między pierwszym (8,3-4) i drugim argumentem (8,5-13), w którym apostoł rozwija temat życia w Duchu. Po pierwsze, odwołując się do generalnych zasad, Paweł akcentuje przeciwieństwo pomiędzy ciałem i Duchem (8,5-8). Życie według ciała prowadzi do śmierci, a jego dążność jest wroga Bogu. Z kolei Duch prowadzi do życia i pokoju. W jasny sposób przekłada się to na życie ochrzczonych (8,9-11): nie żyją oni według ciała, a mając mieszkającego w nich Ducha, należą do Chrystusa i mogą liczyć na to, że Bóg mocą Ducha wskrzesi ich śmiertelne ciała. W w. 12-13 Paweł stwierdza, że ochrzczeni nie są już dłużnikami ciała i nie muszą żyć według niego ${ }^{46}$. Przy pomocy Ducha mogą panować nad popędami ciała, co w konsekwencji prowadzi ich do życia. Znaczy to, że Duch daje im siłę do moralnego życia ${ }^{47}$. Indicativus, którym Paweł opisuje status wierzących w Rz 8,1-13, przeplata się z imperatiwem. Dary Ducha pozostają nieefektywne, jeśli wierzący nie podąża za jego prowadzeniem

w Rz 8, zob. także A. Pitta, „Form and Content of the Propositio in Pauline Letters: the Case of Rom 5.1-8.39", RB 122/4 (2015) 575-591.

43 Por. J.J.J. van Rensburg, „The Children of God in Romans 8”, Neot 15 (1981) 155; C.H. Talbert, „Tracing Paul's train of thought in Romans 6-8”, RevExp 100/1 (2003) 59.

44 Por. Aletti, „Romans 8”, 115.

45 Por. Wilckens, Der Brief an die Römer, II, 129.

46 Por. A. Gieniusz, „«Debtors to the Spirit» in Romans 8.12? Reasons for the Silence”, NTS 59/1 (2013) 61-72.

47 Por. Aletti, „Romans 8”, 116. 
$(\mathrm{Rz} 8,4)$ i nie uśmierca przy Jego pomocy popędów ciała $(\mathrm{Rz} 8,13)$. Widać wyraźnie, że nowe życie w Duchu jest Jego dziełem, a zarazem owocem Jego współpracy z człowiekiem.

Kończąc pierwszą część swojej argumentacji, apostoł włącza w nią obrazy związane z dziecięctwem Bożym wierzących (Rz 8,14-17). Duch, prowadząc ochrzczonych, daje im coraz intensywniej doświadczać ojcowskiej relacji z Bogiem $(8,14)$. Paweł postępuje na zasadzie retorycznego gradatio, opisując najpierw Ducha, który uzdalnia ochrzczonych do zwracania się do Boga „Abba, Ojcze" $(8,15)$. Dalej nieustannie uświadamia im ich godność dzieci Bożych $(8,16)$ oraz oczekujące ich dziedzictwo chwały, którego mogą się spodziewać, uczestnicząc w cierpieniach Chrystusa $(8,17)$. Działanie Ducha nie ogranicza się tylko do przypominania wierzącym ich statusu, ale polega na coraz głębszym wprowadzaniu ich we wspólnotę z Bogiem, dzięki której stają się coraz bardziej podobni do Jego Syna, co z kolei uzdalnia ich do etycznego życia ${ }^{48}$.

Wersy 14-17, które wprowadzają tematy synostwa i cierpienia, można potraktować także jako przejście (transitio) do kolejnej części argumentacji, rozpoczynającej się w w. $18^{49}$. Wers ten kwalifikuje się jako kolejną tezę (subpropositio) podejmującą temat współcierpienia z Chrystusem wprowadzony w w. $17^{50}$. Paweł stwierdza, że obecne cierpienia nie są w stanie zniweczyć przyszłej chwały, która oczekuje wierzących:

8,18: subpropositio: obecne cierpienia nie przekreślają przyszłej chwały wierzących

8,19-22: cierpienie stworzenia jako jęki i bóle, w których rodzi się jego przyszła chwała

8,23-25: cierpienie związane z oczekiwaniem na pełnię zbawienia

8,26-27: cierpienie jako miejsce doświadczenia modlitwy i wstawiennictwa Ducha

8,28-30: Bóg gwarantem przyszłej chwały wierzących

8,31-39: peroratio: zwycięstwo Bożej łaski i nowego życia w ochrzczonych

Według A. Gieniusza apostoł odpowiada tu na dylemat związany z deuteronomistyczną teorią retrybucji, według której cierpienie nieodwołalnie kojarzy się z karą za grzechy ${ }^{51}$. Paweł wydaje się twierdzić, że nie tylko nie przekreśla ono przyszłej chwały wierzących, ale wręcz staje się sposobem na upodobnienie się do Chrystusa i udział w Jego chwale. Tak jak Syn Boży przyjął na siebie ludzką kondycję, ograniczoną słabością i cierpieniem $(8,3)$, aby ostatecznie

48 Por. V. Rabens, The Holy Spirit and Ethics in Paul. Transformation and Empowering for Religious-Ethical Life (WUNT II/283; Tübingen: Mohr Siebeck 2010) 172; Aletti, „Romans 8”, 116.

49 Por. Matand Bulembat, Noyau et enjeux de l'eschatologie paulinienne, 204-206.

50 Por. Gieniusz, Romans 8,18-30, 81-82; Grappe, „Qui me délivrera de ce corps de mort?”, 491; Matand Bulembat, Noyau et enjeux de l'eschatologie paulinienne, 202; Talbert, „Tracing Paul's train of thought in Romans 6-8", 60.

51 Zob. Gieniusz, Romans 8,18-30, 110-111; 160-161. 
przejść do chwalebnego zmartwychwstania $(8,11)$, tak też ochrzczeni, znosząc trudy obecnego życia, zmierzają ku życiu przyszłemu ${ }^{52}$. Rz 8,18 odnosi się do tezy z 8,1, a pośrednio także do tezy głównej w Rz 5,20-21. Cierpienie, wciąż obecne w tym świecie, nie jest oznaką podległości przekleństwu Prawa $(8,1)$ i nie przekreśla królowania łaski prowadzącej do życia wiecznego $(5,20-21)$.

Według Dunna i Moo w Rz 8,10-30 Paweł coraz bardziej zanurza się w rzeczywistości „niedokonanej” (not yet) życia chrześcijańskiego, które wciąż czeka na swoje wypełnienie ${ }^{53}$. Pomiędzy Bożym projektem i obfitością łaski zapośredniczoną przez Ducha a chrześcijańskim „teraz” istnieje napięcie. Można je nazwać eschatologicznym, ponieważ znajdzie ono swoje rozwiązanie tylko na końcu czasów. Obecny świat jest wciąż niedoskonały, w stanie nieustannej transformacji i oczekiwania na objawienie świata przyszłego. Cytowany już Gieniusz zwraca uwagę na fakt, że Duch, paradoksalnie, przyczynia się do budowania tegoż napięcia w chrześcijaninie, dając mu już teraz poznać przedsmak przyszłej chwały ${ }^{54}$. Wierzący tęsknią do rzeczywistości, która na obecną chwilę pozostaje dla nich wciąż nieosiągalna. Podobną, choć jeszcze bardziej radykalną myśl wyraził wcześniej Dunn, według którego działanie Ducha, paradoksalnie, komplikuje egzystencję ochrzczonych z powodu ich nieustannego życia w ciele. Sprawia ono, że wierzący doświadczają rozdarcia pomiędzy pragnieniami ciała i Ducha, pogrążając się czasem wręcz w niechęci do obu tych rzeczywistości ${ }^{55}$.

Trudno zgodzić się z pesymistyczną wizją Dunna, który czyta życie chrześcijańskie w perspektywie nieustannej walki i rozdarcia, znajdując jego obraz w Rz 7,7-25. Według Alettiego i Witheringtona, do których się przyłączamy, Paweł nie opisuje w tym rozdziale egzystencji wierzących, lecz raczej tych, którzy pozostają poza Chrystusem ${ }^{56}$. Interpretacja Gieniusza znacznie lepiej wpisuje się kontekst Rz 1-4, choć rozumowanie apostoła w Rz 8,18-30 nie musi kierować się jedynie przeciw klasycznym elementom deuteronomistycznej teorii retrybucji. Autor zwraca uwagę na fakt, że takie ukierunkowanie argumentacji Pawła dobrze odpowiada żydowskiemu interlokutorowi apostoła w Rz 1-3, ale w rozdziałach tych mamy także do czynienia z argumentacją, która doskonale przemawia do pogan. Podobnie rzecz ma się z problemem cierpienia w Rz 8,18-30.

52 Por. Aletti, „Romans 8”, 116.

53 Zob. Dunn, Romans 1-8, 302-303; Moo, The Epistle to the Romans, 390.

54 Zob. Gieniusz, Romans 8,18-30, 195-196.

55 Zob. J.D.G. Dunn, Jesus and the Spirit. A Study of the Religious and Charismatic Experience of Jesus and the First Christians as Reflected in the New Testament (New Testament Library; London: S.C.M. Press 1975) 312-318

56 Por. J.-N. Aletti, „Romans 7:7-25 and Galatians 5:17. Questions and Proposals”, New Approaches for Interpreting the Letters of Saint Paul. Collected Essays: Rhetoric, Soteriology, Christology and Ecclesiology (SubBi 43; Roma: Gregorian \& Biblical Press 2012) 81-84; Witherington Hyatt, Paul's Letter to the Romans, 195-196; Kowalski, „Nowe życie jak ziarno gorczycy”, 468-477. 
Przeświadczenie o cierpieniu i nieszczęściu spadającym na człowieka jako kara bogów jest wspólne dla całego świata starożytnego i dobrze wpisuje się w uniwersalną i egzystencjalną linię argumentacji apostoła ${ }^{57}$. Definiując cierpienie jako drogę do osiągnięcia przyszłej chwały wiecznej, apostoł korzystać może także z szerokiego spektrum tradycji starożytnych, od filozoficznych po mądrościowe i prorockie obecne w $\mathrm{ST}^{58}$. Tym, co decyduje o absolutnej nowości myśli Pawła, jest początkowe powiązanie cierpienia z Chrystusem, dzięki czemu staje się ono sposobem na uczestniczenie w Jego przyszłej chwale (Rz 8,17).

Jak rozwija się argumentacja Pawła w stosunku do tezy, którą postawił on w Rz 8,18? Niezależnie od tego, jak szeroko potraktujemy postawiony tu problem, dotyczy ona sensu cierpienia w życiu wierzących. Według Gieniusza Paweł odpowiada na nie w trzech krokach ${ }^{59}$. W w. 19-22 wskazuje, że cierpienie całego stworzenia związane jest $\mathrm{w}$ istocie $\mathrm{z}$ jego oczekiwaniem na objawienie się synów Bożych (w. 19), uwolnienie z niewoli zepsucia i uczestniczenie w wolności

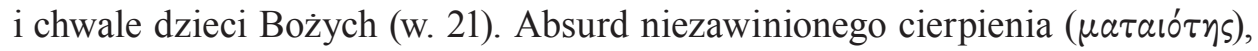
któremu został poddany cały stworzony świat, niewątpliwie sam w sobie jest źródłem jęku stworzenia, lecz dzięki Duchowi pusty, paradoksalny ból zamienia się w ból rodzenia, z którego wyłoni się przyszła rzeczywistośćc ${ }^{60}$. W drugim kroku (w. 23-25) apostoł tłumaczy, że teraźniejsze cierpienie wierzących to nic innego, jak oczekiwanie na ich pełne przybranie za synów i odkupienie ciała. Pierwsze dary Ducha, zapowiadające pełnię, i nadzieja zbawienia mogą paradoksalnie przyczyniać się do wzmożonego cierpienia i tęsknoty ochrzczonych, ale

57 Na temat gniewu bogów ściągającego na ludzi cierpienie, zob. Platon, Phaedr. 244d-e; Liwiusz, Hist. 4,9,3; 5.14.3; 22,9,1; Tacyt, Ann. 1,39; Hist. 2,38.

58 Por. Prz 3,11-12; 12,1; 13,1; Oz 2,4-19; Iz 1; Jr 2-6; Iz 53,10-12. Na temat podobieństw pomiędzy strategią retoryczną Pawła w Rz 8,38-39 i grecko-rzymską parenezą zob. J.L. Jaquette, „Life and Death, Adiaphora, and Paul's Rhetorical Strategies", NovT 38/1 (1996) 30-54, zwł. 42-46; R. Jewett, „Impeaching God's Elect. Roman 8,33-37 in Its Rhetorical Situation”, Paul, Luke and the Graeco-Roman world. Essays in Honour of Alexander J.M. Wedderburn (red. A.J.M. Wedderburn - A. Christophersen) (JSNTSup 217; London - New York: T \& T Clark 2003) 45-49.

59 Zob. Gieniusz, Romans 8,18-30, 285, 287. Zob. także van Rensburg, „The Children of God in Romans 8", 156; Matand Bulembat, Noyau et enjeux de l'eschatologie paulinienne, 214-247.

60 Paweł w Rz 8,20 raczej opisuje paradoksalną sytuację wierzących zmagających się z niezawinionym cierpieniem, a nie ich grzeszność. Gieniusz, Romans 8,18-30, 151-153. Kontra L.J. Braaten, „The Groaning Creation. The Biblical Background for Romans 8:22”, BR 50 (2005)

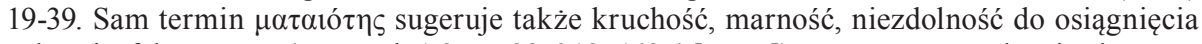
celu, nieefektywność (por. Koh 1,2; Ps 38,6.12; 143,4 [LXX]). Fenomeny te odnosić się mogą do kondycji stworzenia, które po grzechu pierworodnym nie jest w stanie osiągnąć właściwego sobie celu, spełnienia, pełni życia. Rz 8,21 sugeruje, że $\mu \alpha \tau \alpha ı$ ó $\rceil_{\varsigma}$ łączy się także z zepsuciem, czy to wynikającym z grzechu, czy też z działania śmierci. Na temat tegoż pojęcia zob. Sanday - Headlam, A critical and Exegetical Commentary on the Epistle of the Romans, 208; Fitzmyer, Romans, 507; B. Byrne, Romans (Sacra Pagina Series 6; Collegeville, MN: Liturgical Press 1996) 260; Jewett - Kotansky, Romans, 513; Dunn, Romans 1-8, 470; Kowalski, „Nowe życie jak ziarno gorczycy”, 477 n. 90. 
równocześnie motywują ich do wytrwałego oczekiwania. Wreszcie w w. 26-27 Paweł łączy słabość i cierpienie wierzących z niewymownymi błaganiami Ducha, który wstawia się za nimi. Innymi słowy doświadczenia obecnego czasu stają się przestrzenią, w której spotykają się oni z obecnością i modlitwą Ducha.

Można powiedzieć, że na każdym z wymienionych etapów Duch jest postacią kluczową dla przełamania bezsensu ludzkiego cierpienia. W Rz 8,17 apostoł ukazuje go jako Tego, który prowadzi wierzących do przyszłej chwały, nie pozwalając, aby pośród życiowych doświadczeń utracili ją z oczu. Uczestniczenie w wolności i chwale dzieci Bożych jest jego dziełem $(8,21)$, podobnie jak przemiana bezproduktywnego ludzkiego jęku w bóle porodowe $(8,22)$. Dalej Duch wraz ze swymi pierwszymi darami złożonymi w wierzących zapala i podtrzymuje w nich nadzieję przyszłej przemiany i pełni zbawienia, którego oczekują (8,23-25). Wreszcie On także zbliża się do chrześcijanina w słabości, rozumianej generalnie jako kondycja człowieka w tym świecie, i daje mu się rozpoznać w modlitwie i wstawiennictwie przed Bożym obliczem $(8,26-27)^{61}$.

Wersy 28-30 stanowią zamknięcie argumentacji w Rz 8,18-30 i potwierdzają to, co Paweł stwierdził w tezie pomocniczej w w. $18^{62}$. Cierpienia tego świata nie są w stanie odebrać wierzącym przyszłej chwały, ponieważ z miłującymi Go Bóg współdziała we wszystkim, realizując swój plan zbawienia $(8,28)$. Doświadczenie słabości służy ostatecznie upodobnieniu ich do Chrystusa, aby stał się On pierworodnym pośród wielu braci $(8,29)$. Równocześnie stanowi tylko pierwszy krok stwarzania wierzących na Jego obraz, ponieważ ostatecznie cały proces prowadzi do bycia podobnymi do Niego w Jego chwale $(8,30)$. Znów trudno oprzeć się wrażeniu, że w procesie tym uczestniczy w szczególny sposób Duch. To On w Rz 5,5 rozlewa miłość Bożą w sercach wierzących, zaś w Rz 8,17 gwarantuje skuteczność przejścia do współuczestniczenia w cierpieniach do przyszłej chwały.

Ostatnia już część rozdziału ósmego, w. 31-39, to triumfalny hymn na cześć Boga, który prowadzi ochrzczonych do pełni zbawienia w Chrystusie. Wersy te można zakwalifikować jako zakończenie (peroratio) całej mowy Pawła w Rz 5-8 ${ }^{63}$. Fakt ten potwierdza zbieżność słownictwa między Rz 8,31-39 i Rz 5,1-11, które stanowi wstęp (exordium) do całej Pawłowej argumentacji

61 Por. Dunn, Romans 1-8, 477; Moo, The Epistle to the Romans, 523; Gieniusz, Romans 8,18-30, 212-214

62 Por. Gieniusz, Romans 8,18-30, 251-253, 287.

63 Por. Aletti, „Romans 5-8”, 74; Aletti, „Romans 8”, 112; Gieniusz, Romans 8,18-30, 49-51; F. Belli, „Un'allusione a Is 50,8-9 in Rm 8,31-34”, RivB 50 (2002) 165; Grappe, „Qui me délivrera de ce corps de mort?", 491-492; Matand Bulembat, Noyau et enjeux de l'eschatologie paulinienne, 202-204. Na temat retoryki i stylu tej sekcji zob. także G. Schille, „Die Liebe Gottes in Christus. Beobachtungen zu Rm 8,31-39”, ZNW 59 (1968) 230-244; A.H. Snyman, „Style and the Rhetorical Situation of Romans 8.31-39”, NTS 34 (1988) 218-231. 
w tych rozdziałach. W końcowej części mowy retor zazwyczaj wraca do jej głównych tematów, przypominając je swoim słuchaczom i dbając o to, aby dobrze zapisały się w ich pamięci. W tym celu użyć można także znacznej dawki pathosu (apelu do uczuć). Oba elementy znajdujemy w Rz 8,31-39. Paweł przywołuje tematy sprawiedliwości i usprawiedliwienia $(8,33)$, śmierci $(8,34.38)$ i życia $(8,38)$, które pojawiły się w poprzednich rozdziałach. Wierzący, mając po swej stronie Boga, który wydał za nich własnego Syna, mogą spodziewać się pełni Jego darów (8,31-33). Wstawia się za nimi sam Chrystus zasiadający po prawicy Ojca $(8,34)$. Apostoł, wracając do pojawiających się w Rz 5,1-11 tematów cierpienia, stwierdza, że nic nie jest w stanie odłączyć ochrzczonych od miłości Chrystusa i miłości Boga w Chrystusie (8,35-39). Klimat radosnej pewności zbawienia, jaki pojawia się w Rz 5,1-11, powraca w Rz 8,31-39. Choć apostoł nie wspomina w nim o Duchu, Jego postać łączy się wyraźnie z darem Bożej miłości (Rz 5,5). Jego rolę jako wstawiennika przed Bogiem w Rz 8,34 przejmuje Chrystus. Świadczy to o nierozerwalności dzieła Syna i Ducha, które Paweł potwierdza w Rz 8,3-4, ukazując Chrystusa jako Tego, który otwiera drogę dla działania Ducha w chrześcijaninie.

Czego dowiadujemy się ze szczegółowej analizy struktury retorycznej Rz 8? Fakt, że Duch pojawia się w finale argumentacji Pawła dotyczącej nowego życia w Rz 5-8 sugeruje, że jest on dla tegoż tematu kluczowy ${ }^{64}$. Można go także znaleźć w obu częściach dyskursu apostoła w Rz 8. W Rz 8,1-13 Paweł czyni Go odpowiedzialnym za życie wolne od wyroku potępiającego, które wydają na człowieka grzech i Prawo. Duch jawi się jako dawca życia zarówno w wymiarze doczesnym, jak i wiecznym $(8,2.6 .11 .13)$. Prowadzi On wierzących i odpowiada za ich nowe życie w wymiarze etycznym, w którym nie idą za pożądaniami ciała (8,4.5.9.10.13). Mieszka On w ochrzczonych, czyniąc z nich własność Chrystusa $($ Rz 8,9$)$. Duch nie tylko uświadamia wierzącym ich status dzieci Bożych, ale także kształtuje go, pomaga przeżywać i wykorzystuje jako imperatyw moralny (8,14-17). W drugiej części argumentacji Pawła w Rz 8,18-30 Duch przemienia obecne cierpienia $\mathrm{w}$ drogę do zjednoczenia z Chrystusem, gwarancję i zapowiedź przyszłej chwały oraz przestrzeń spotkania ze sobą. W jaki sposób rozumieć Jego prowadzenie i związek z życiem etycznym? Czy opanowuje On wierzących i działa w ich imieniu, czy też potrzebuje aktywnego współdziałania człowieka? Jak wyobrazić sobie Jego zamieszkiwanie w nas? Zwrócimy się teraz ku badaczom, którzy odpowiedzi na te pytania poszukiwali, wskazując na konceptualny związek Pawłowej pneumatologii ze światem stoickim.

64 Por. Lee, Paul's Gospel in Romans, 429. 


\section{Ujęcie Ducha u Pawła w powiązaniu z teoriami stoickimi}

Wartościowy przegląd publikacji poświęconych Duchowi w anglosaskim środowisku biblijnym znaleźć możemy w ze wszech miar godnej polecenia monografii Volkera Rabensa The Holy Spirit and Ethics in Paul ${ }^{65}$. Publikacja ta stanowić będzie dla nas punkt odniesienia, który uzupełnimy o innych pominiętych w niej autorów odnoszących się do wątków stoickich. Myśląc o penumatologii Pawła i jej osadzeniu w kontekście grecko-rzymskim, warto rozpocząć od Hermana Gunkela i jego dzieła Die Wirkungen des heiligen Geistes (1888) ${ }^{66}$. Według autora Paweł rozciąga działanie Ducha na wszystkie sfery życia chrześcijanina, czyniąc je w całości darem oraz cudem i przenosząc w wymiar ponadnaturalny (s. 111). Duch przejmuje pełną kontrolę nad człowiekiem, tak że ten nie może on już realizować własnej woli, lecz wolę Bożą (s. 93-94). Równocześnie niemiecki egzegeta stawia tezę, według której dla zrozumienia myśli Pawła o Duchu musimy zanurzyć się nie tyle w Starym Testamencie, ile w popularnej myśli żydowskiej, którą przesiąknięte były wspólnoty chrześcijańskie I w. Gunkel twierdzi, że Paweł pojmuje Ducha jako substancję i że ideę tę zaczerpnął on z kręgu judaizmu swoich czasów ${ }^{67}$. Co ciekawe, autor radykalnie oddziela zarówno judaizm, jak i Stary Testament od prądów filozoficznych, twierdząc, że nie miały one wpływu na obraz Boga (s. 61-62) czy też materialistyczne pojmowanie Ducha przez Żydów (s. 63). Gunkel myśli tu wyraźnie o filozofii platońskiej, nie biorąc w ogóle pod uwagę nurtu stoickiego, w którym pojawia się właśnie idea materialnego Ducha ${ }^{68}$. Dla autora, który idzie tu za Friedländerem, Żydzi nie mieli tak dalece wykształconego zmysłu abstrakcji, aby pojmować Ducha jako byt niematerialny (s. 59) ${ }^{69}$. Gunkel walczy w obronie realizmu chrześcijańskiego i literalnej interpretacji tekstów biblijnych, wbrew dominującemu w jego czasach idealizmowi filozoficznemu (s. 65).

65 Zob. Rabens, The Holy Spirit and Ethics in Paul, 2-14, 253-306.

66 Zob. H. Gunkel, Die Wirkungen des heiligen Geistes nach der populären Anschaunngen der apostolischen Zeit und der Lehre des Apostels Paulus (Göttingen: Vandenhoeck \& Ruprecht 1888). W niniejszym opracowaniu korzystać będziemy z angielskiego tłumaczenia H. Gunkel, The Influence of the Holy Spirit. Popular View of the Apostolic Age and the Teaching of the Apostle Paul. Translated by Roy A. Harrisville and Philip A. Quanbeck II (Minneapolis, MN: Fortress Press 2008).

67 Autor w szczególny sposób odnosi się do 2 Ba 51, cytując także m.in.: En 14,20; 25,3; 71,10. Zob. Gunkel, The Influence of the Holy Spirit, 62.

68 E. Wasserman, „Paul among the Philosophers. The Case of Sin in Romans 6-8”, JSNT 30/4 (2008) 409-410 mało przekonująco argumentuje za obecnością w Rz 8 dyskursu platońskiego na temat Ducha i ciała.

69 Por. L. Friedländer, Darstellungen aus der Sittengeschichte Roms in der Zeit von August bis zum Ausgang der Antonine (Leipzig ${ }^{5}$ 1881) III, 701. 
Kolejny z badaczy kręgu anglosaskiego, który nie ma już oporów, aby odwołać się do obecności stoickich koncepcji Ducha u Pawła, to Richard B. Hoyle, autor The Holy Spirit in St. Paul (1927) ${ }^{70}$. Autor stwierdza podobieństwo pomiędzy doktryną o Duchu zawartą w Księdze Mądrości a pismami św. Pawła. Niezależnie od tego, czy Paweł korzystał z Księgi Mądrości, pozostaje ona, według niego, pod wpływem idei stoickich i podobnie rzecz ma się z nauczaniem apostoła (s. 218-219). Stoickie pojmowanie pneumy jako mieszaniny ognia i powietrza, utożsamianie jej z Bogiem oraz zamieszkiwanie w człowieku dostarczyłyby Pawłowi koncepcji i języka, którym starał się dotrzeć do swych słuchaczy (s. 223). Zasadnicze zręby Pawłowej teorii poznania noszą znamiona stoickie i nie znaczy to, że jest to wizja naukowa; to popularny punkt widzenia ludzi I w. (s. 230). Jego elementy widać u Filona, ale także w różnorodnych dziełach natury medycznej. Paweł, w odróżnieniu od dominujących w jego czasach szkół filozoficznych, nie skupia się na tym, jak Duch działa, ale do czego prowadzi; Jego celem jest poznanie Boga (s. 241). Apostoł zgadza się ze stoikami, ale także z wieloma myślicielami pitagorejskimi, platońskimi i arystotelesowskimi, co do fundamentalnego znaczenia pneumy jako zasady życia i łącznika między Bogiem i człowiekiem (s. 247). Unikając stoickiego materializmu i immanencji, Paweł używa jednak stoickich pojęć dla opisania zrozumiałej dla wszystkich boskiej siły, która wkracza w ludzki świat i przemienia człowieka (s. 262-263). Opisuje Go językiem personalistycznym jako pochodzącego od Boga.

Wracając do badaczy kręgu niemieckojęzycznego, również Ernst Käsemann przyznaje, że Pawłowa pneumatologia rodzi się pod wpływem kontaktu ze środowiskiem hellenistycznym, lecz zasadniczy wpływ przypisuje tu gnozie. Sakramentologia Pawła prezentuje się jako bliska ideom gnostyckim. Charakteryzuje ją automatyzm i materialistyczne pojmowanie Ducha ${ }^{71}$. Oprócz wpływów gnostyckich Käsemann identyfikuje także u Pawła stoickie idee immanentnej pneumy. Równocześnie apostoł różni się zasadniczo od stoików, podkreślając opozycję między ciałem i Duchem ${ }^{72}$. Wpływ hellenistycznej penumatologii na Pawła przejawia się jednak w tym, że pojmuje on Ducha jako materialną i substancjalną siłę. Apostoł, podobnie jak starożytni jego czasów, nie zna pojęcia energii bez substratu materialnego, skłaniając się w ten sposób ku hellenistycznemu materializmowi ${ }^{73}$. Wierzący przyjmują Ducha w sakramentach, w szczególny

70 Zob. R.B. Hoyle, The Holy Spirit in St. Paul (London: Hodder and Stoughton 1927).

71 Zob. E. Käsemann, „The Pauline Doctrine of the Lord's Supper”, Essays on New Testament themes (SBT 41; London: SCM Press 1964) 115-116.

72 Zob. E. Käsemann, Leib und Leib Christi. Eine Untersuchung zur paulinischen Begrifflichkeit (BHT 9; Tübingen: Mohr Siebeck 1933) 126.

73 Zob. Käsemann, Leib und Leib Christi, 135; E. Käsemann, Commentary on Romans (London: SCM Press 1980) 212. 
sposób w chrzcie i Eucharystii (1 Kor 10,3-4) $)^{74}$. O ile w swoich wcześniejszych dziełach Käsemann wydawał się szkicować naturalistyczne działanie pneumy, która w chrzcie włącza wierzącego w naturę Chrystusa i w jego sferę panowania, o tyle później mówi o wolnym, osobowym działaniu Ducha, Jego objawianiu obecności Chrystusa i pośredniczeniu w nowym życiu ${ }^{75}$. Autor w pewien sposób dystansuje także apostoła od stoickiego materializmu, twierdząc, że adaptuje on jedynie język, którym posługiwało się środowisko hellenistyczne, a konkretnie wspólnota w Koryncie ${ }^{76}$. Uczeń Käsemanna Peter Stuhlmacher będzie utrzymywał, podobnie jak jego nauczyciel, materialny charakter Ducha, który odpowiada za substancjalno-ontologiczną przemianę $\mathrm{w}$ człowieku ${ }^{77}$. Z drugiej strony widzi w nim obecność Chrystusa, która wprowadza człowieka w komunię z Bogiem ${ }^{78}$.

W podobnie substancjalnym kluczu czyta Ducha Kurt Stalder, który w swojej książce Das Werk des Geistes in der Heiligung bei Paulus (1962) zarzuca badaczom abstrahowanie w swoich opracowaniach od rozważań nad naturą pneumy ${ }^{79}$. Autor ukazuje uświęcające działanie Ducha na podstawie Rz 8, stwierdzając, że nie jest on tu przedstawiony ani jako hipostaza, ani jako energia; Duch jest ni mniej, ni więcej tylko Bogiem (s. 26-35, 47). Paweł mógł Go pojmować jako substancję, ale nie w sensie materialnego substratu wspólnego Bogu i człowiekowi (s. 64-67). Ostatecznie Stalder porzuca koncepcję substancjalności Ducha jako zbyt dwuznaczną na rzecz koncepcji bytu (Sein) (s. 64-67). Kwestia Jego zamieszkiwania w człowieku nie może zostać, według autora, sprowadzona do żadnej teorii czy modelu filozoficznego, ponieważ jest ona cudem (s. 68). Analizując Rz 8, Stalder przypisuje Duchowi głównie właściwości kognitywne i wolitywne. W Rz 8,5 doprowadza on wierzących do poddania się swemu prowadzeniu, zaś w Rz 8,14 zwiększa ich samoświadomość, przekonując, że są synami Bożymi i w ten sposób wzywa do odpowiedzialności za nowe życie. W żadnym z wymienionych przypadków Jego działanie nie zasadza się na przemianie człowieka ani uzdolnieniu go do życia moralnego, lecz jedynie na przekazaniu koniecznej informacji i motywacji (s. 485).

74 Zob. Käsemann, „The Pauline Doctrine of the Lord's Supper”, 114.

75 Por. Rabens, The Holy Spirit and Ethics in Paul, 9. Z odniesieniem do Käsemann, Leib und Leib Christi, 162, 175, 168, 165, 176, 184-185; Käsemann, „The Pauline Doctrine of the Lord's Supper", 118-119.

76 Zob. Käsemann, „The Pauline Doctrine of the Lord's Supper”, 117.

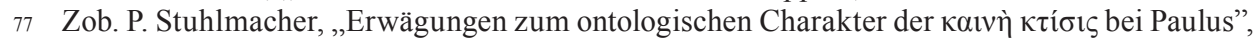
EvT 27/1 (1967) 24-25.

78 Zob. P. Stuhlmacher, Gerechtigkeit Gottes bei Paulus (FRLANT 87; Göttingen: Vandenhoeck \& Ruprecht 1965) 224-225; Stuhlmacher, „Erwägungen zum ontologischen Charakter der кaivì

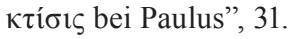

79 Zob. K. Stalder, Das Werk des Geistes in der Heiligung bei Paulus (Zürich: EVZ-Verlag 1962). 
Materialny charakter Ducha u Pawła przyjmuje także Friedrich Horn w swojej publikacji Das Angeld des Geistes (1992) ${ }^{80}$. Ideę materialnego Ducha autor przypisuje zarówno judaizmowi, jak i hellenizmowi czasów apostoła. Znajdujemy w nich poglądy, według których pneuma dla znalezienia się w człowieku i oddziaływania na niego używa materialnych substancji, takich jak woda czy pożywienie. Wizję materialnego Ducha i związaną z nim sakramentologię Paweł miałby przejąć od Koryntian (s. 43-48, 57-59, 430). Horn rozróżnia substancjalną i materialną formę bytowania Ducha. O tej pierwszej mówi, kiedy opisuje Ducha zamieszkującego w wierzącym i można odnieść wrażenie, że jest ona ekwiwalentem osobowej obecności (Rz 8,9; s. 60). Z kolei o materialnym Duchu autor mówi, kiedy wchodzi On w kontakt $\mathrm{z}$ materią i wiąże się z nią, jak choćby w sakramentach (s. 60, 405, 429-430). Sposób, w jaki według Horna Paweł myśli o przekazywaniu materialnego Ducha w sakramentach, jest na wskroś hellenistyczny (s. 400). Można go porównać do płynu lub substancji wchłanianej przez wierzących, która dalej przemienia od wewnątrz ich całą egzystencję. Horn twierdzi, że Paweł bardzo oszczędnie odwołuje się do Ducha w nauczaniu etycznym, ograniczając Jego rolę praktycznie do przekaziciela Bożej miłości (Rz 5,5) ${ }^{81}$. Równocześnie ukazuje ewolucję Pawłowej pneumatologii, która od kategorii funkcjonalnych (1 Tes) przechodzi do wizji Ducha jako hipostazy (Rz 8), z akcentami materialistycznymi w fazie środkowej, czyli w korespondencji korynckiej ${ }^{82}$.

W pierwszej połowie XX w. oraz w latach pięćdziesiątych i sześćdziesiątych obszar niemieckojęzyczny stanowił główne pole rozwoju badań na Pawłową pneumatologią. Sytuacja zmieniła się wraz nadejściem lat siedemdziesiątych, w których zaznacza się coraz wyraźniej wpływ anglo-amerykański ${ }^{83}$. W 1995 r. Dale B. Martin opublikował dzieło The Corinthian Body, które stało się inspiracją i punktem odniesienia dla wielu współczesnych biblistów szukających powiązania pomiędzy pneumatologią Pawła i teoriami stoickimi oraz medycznymi na temat

80 Zob. F.W. Horn, Das Angeld des Geistes. Studien zur paulinischen Pneumatologie (Göttingen: Vandenhoeck et Ruprecht 1992).

81 Poglądy autora w tej kwestii można znaleźć w artykule: F.W. Horn, „Wandel im Geist. Zur pneumatologischen Begründung der Ethik bei Paulus", KD 38/2 (1992) 149-170.

82 Zob. Horn, Das Angeld des Geistes, 119-383. Trzy fazy nie wykluczają się wzajemnie. Także u końca swojej twórczości Paweł posługuje się kategoriami funkcjonalnymi oraz materialistycznymi. Na ten temat zob. także F.W. Horn, „Holy Spirit”, The Anchor Yale Bible Dictionary (red. D.N. Freedman - G.A. Herion - D.F. Graf - J.D. Pleins - A.B. Beck) (New York: Doubleday 1992) III, 275-276; A.C. Thiselton, The Holy Spirit - in Biblical Teaching, through the Centuries, and Today (Grand Rapids, MI: Eerdmans 2013) 439.

83 Zob. J.D.G. Dunn, Baptism in the Holy Spirit. A Re-Examination of the New Testament Teaching on the Gift of the Spirit in Relation to Pentecostalism Today (Philadelphia: Westminster Press 1970); Dunn, Jesus and the Spirit. Na temat Dunna i jego twórczości, zob. także Rabens, The Holy Spirit and Ethics in Paul, 288-293. 
pneumy $^{84}$. Autor w zwięzły sposób wykłada w nim najpierw stoickie pojęcie materialnego Ducha, który w popularnych działach filozoficznych i medycznych oznacza pierwiastek życia, byt kognitywny odpowiedzialny za percepcję i postrzeganie świata oraz za życie moralne człowieka (s. 13, 21-25). Martin po wielokroć odnosi się do poglądów stoickich, opisując zawierające się w nich rozumienie natury (s. 9-10), materii (s. 12), duszy (s. 14) oraz mędrca (s. 72). Równocześnie podpisuje się pod poglądem, który widzieliśmy już u Gunkela oraz Käsemanna, według którego starożytni nie rozróżniali materialnego i niematerialnego aspektu rzeczywistości, wszystko pojmując jako swego rodzaju materię (s. 7-15). Według Martina 1 Kor 15 ukazuje szczególne wpływy hellenistyczne, opisując ciało zmartwychwstałe na podobieństwo stoickich koncepcji ciał niebiańskich (s. 118-119, 126). Paweł przyjmowałby tu kosmologiczną hierarchię ciał znaną stoikom, aby na jej podstawie wytłumaczyć Koryntianom, którzy także ją przyjmowali, negowany przez nich fakt zmartwychwstania (s. 129). Ostatecznie autor stwierdza, że Pawłowa teologia jest apokaliptyczna, lecz nagina się w aspektach kosmologicznych i w rozumieniu świata fizycznego do myśli greckiej (s. 135).

Śladami Martina podążyli następnie inni badacze. Michelle Lee, odrzucając krytykowaną przez Martina, obcą starożytnym dychotomię ciało-Duch, proponuje stoicyzm jako narzędzie interpretacji syntagmy „ciało Chrystusa” u Pawła ${ }^{85}$. Według autora wyrażenie to należy rozumieć dosłownie, a historyczny kontekst jego interpretacji stanowią właśnie stoickie teorie na temat materialnej pneumy. Mówią one o Duchu jako dawcy jedności i spoiwie całego wszechświata, rozumianego jako kosmiczne ciało (s. 51-52). Dzięki niemu byty łączą się ze sobą, zachowując swoje właściwości (stoicka teoria krasis, s. 52-53), co doskonale widać w nauczaniu św. Pawła na temat ciała Chrystusa w 1 Kor 12 (s. 124-125). Paweł, według Lee, korzysta ze stoickiej idei ciała Chrystusa jako makrokosmosu, w którym żyją wspólnoty chrześcijańskie (s. 135-136) i w którym Duch nie znosi podziałów społecznych (s. 137-138), odpowiadając równocześnie za więź pomiędzy poszczególnymi członkami (s. 148-149).

Idąc dalej śladem popularnych materialnych koncepcji Ducha, Troy Martin poszerza obszar analizy Pawłowej pneumy o teksty medyczne ${ }^{86}$. Choć różnią się one pod wieloma względami od myśli apostoła, według autora prezentują się równocześnie jako bardzo interesujący materiał porównawczy (s. 106). W starożytnych teoriach medycznych pneuma pobierana z powietrza przez płuca i pory

84 Zob. D.B. Martin, The Corinthian Body (New Haven: Yale University Press 1995).

85 Zob. M.V. Lee, Paul, the Stoics, and the Body of Christ (SNTSMS 137; Cambridge: Cambridge University Press 2006)

86 Zob. T.W. Martin, „Paul's Pneumatological Statements and Ancient Medical Texts”, The New

Testament and Early Christian Literature in Greco-Roman Context. Studies in Honor of David E. Aune (red. D.E. Aune - J. Fotopoulos) (NovTSup 122; Leiden - Boston: Brill 2006) 105-126. 
w skórze krąży w organizmie specjalnymi arteriami i dociera do serca i mózgu oraz układu nerwowego (s. 107-111). Autor cytuje antyczne teksty mówiące o jej właściwościach kognitywnych, stymulujących myślenie (s. 111-114) oraz o jej życiodajnej naturze, sytuującej ją w kategorii pokarmów fizycznych (s. 114-115). Troy Martin stwierdza, że Paweł mógł wyobrażać sobie wstępowanie Ducha w człowieka poprzez uszy (Ga 3,1-5) lub pory w skórze i usta podczas chrztu i Eucharystii (1 Kor 12,13) (s. 115-119) ${ }^{87}$. Duch w Rz 5,5 prezentuje właściwości kognitywne, lokując się w centrum wolitywnym, sercu, oraz prowadząc, czyli wspomagając swą motywacją działanie wierzących w Rz 8,14 (s. 119-120). Duch daje także życie, uwalniając od grzechu i wskrzeszając wierzących w Rz 8,2.11 (s. 125). Ostatecznie starożytna fizjologia pneumy stanowi, według autora, cenne tło dla zrozumienia jego działania u Pawła (s. 125-126).

Kolejną autorką, która odwołuje się do popularnych teorii filozoficznych i medycznych jako tła myśli Pawła, jest Caroline Johnson Hodge ${ }^{88}$. Dla rozjaśnienia Pawłowego obrazu adopcji w Rz 8,14-17 odnosi się ona do stoickiej teorii na temat pneumy i funkcji spełnianej przezeń w łączeniu się substancji (krasis) (s. 75-76). W tekstach medycznych podkreśla się rozrodczy, mobilny i boski charakter pneumy. Przenikając przez inne obiekty materialne i byty, odpowiada ona za ich połączenie bez zmieszania. W Rz 8,14-17 pneuma w sercach wierzących, według Johnson Hodge, tworzy nowe więzy pokrewieństwa i czyni to dosłownie. Poganie, otrzymując pneumę, przyswajają sobie część substancji Chrystusa. W ten materialny i dotykalny sposób można pojąć specyficzną nową relację, którą w Rz 8,14-17 Paweł opisuje za pomocą metafory adopcji. Synostwo przyjmuje tu wymiar zarówno fizyczny, jak i duchowy, podobnie jak obraz włączenia w ciało Chrystusa i bycia jedno z Nim.

Te same odniesienia do stoickiej teorii krasis u Pawła odnaleźć można u Stowersa, który opowiada się za dosłownym rozumieniem Pawłowego obrazu bycia „w Chrystusie” ${ }^{89}$. Autor jest obrońcą Pawłowego realizmu, który, w przeciwieństwie do współczesnego ujęcia realizmu, nie opiera się na dychotomiach między naturalnym i ponadnaturalnym, duchem i materią (s. 355). W ujęciu tym pobrzmiewają postulaty Gunkela i Martina. Stowers nawiązuje także do Johnson Hodge. Komentując naturę i rolę Ducha w Rz 8, autor odwołuje się do

87 Troy Martin idzie tu za H.-J. Klauck, Herrenmahl und hellenistischer Kult. Eine religionsgeschichtliche Untersuchung zum ersten Korintherbrief (NTAbh 15; Münster: Aschendorff 1982) 334-335.

88 Zob. C. Johnson Hodge, If Sons, then Heirs. A Study of Kinship and Ethnicity in the Letters of Paul (Oxford - New York: Oxford University Press 2007).

89 Zob. S.K. Stowers, „What Is «Pauline Participation in Christ»?”, Redefining First-Century Jewish and Christian Identities. Essays in Honor of Ed Parish Sanders (red. F.E. Udoh - S. Heschel - M.A. Chancey - G. Tatum) (Christianity and Judaism in Antiquity Series 16; Notre Dame, IN: University of Notre Dame Press 2008) 352-371. 
języka starożytnej genetyki i pochodzenia, dzięki któremu zrozumieć można podobieństwo wierzących do Chrystusa (Rz 8,29-30). Gwarantuje je Duch, który dosłownie nosi w sobie obraz ojca, przekazując go najpierw Chrystusowi, a potem wszystkim ochrzczonym (s. 361-362). Duch, który działał w Chrystusie podczas zmartwychwstania, mieszka teraz w wierzących, którzy nie tylko należą do Niego, ale fizycznie trwają w Nim, nosząc w sobie Jego część (Rz 8,9). Fakt, że Paweł tak łatwo przechodzi od Ducha Bożego do ducha ludzkiego (por. Rz 8,14-17), sugeruje, według Stowersa, że uczestniczy on w kulturze hellenistycznej, która w ten właśnie sposób pojmowała pneumę. Apostoł odnosi się do jej popularnej charakterystyki i działania w świecie łącznie z teorią krasis, która pomaga mu wyrazić myśl o zjednoczeniu Chrystusa z człowiekiem (s. 362-363).

Intuicje Martina na temat stoickich koncepcji Ducha u Pawła podjął wreszcie i rozwinął Troels Engberg-Pedersen, autor Paul and Stoics (2000) i Cosmology and Self (2010) ${ }^{90}$. W pierwszej książce argumentuje on za wpływem stoickiej kosmologii i teorii poznania na Pawła. W drugim dziele ukazuje, jak dalece Paweł włącza w swoje pojmowanie pneumy zarówno żydowskie kategorie apokaliptyczne, jak i kategorie stoickie. Autor postuluje podwójne - metaforyczno-kognitywne i fizyczne, czy też kosmologiczne (dosłowne), odczytanie języka Pawła (s. 1). Engberg-Pedersen uprawia egzegezę filozoficzną, nie twierdząc, że Paweł był filozofem, ale dowodząc, że w jego tekstach znajdują się elementy pojmowania świata charakterystyczne dla filozofii (s. 2-3). Celem drugiej publikacji jest także przezwyciężenie dychotomii widocznej w pozycjach Gunkela, Käsemanna czy Martina, która umiejscawia apostoła tylko w jednym, żydowskim/apokaliptycznym bądź hellenistycznym/filozoficznym środowisku (s. 8-9, 15-16). Według Engberg-Pedersena Paweł czerpie zarówno z apokaliptycznych, jak i filozoficznych idei, nie bojąc się także przyjąć za swoje stoickie kategorie materialnego i immanentnego Ducha. Za Gunkelem autor powtarza, że apostoł jest realistą, nie idealistą (s. 19). Pneuma w jego ujęciu jest konkretna, dotykalna i materialna.

W rozdziale pierwszym Engberg-Pedersen analizuje ontologię Pawłowego pojęcia pneumy obecną w 1 Kor 15. Już wcześniej autor stwierdza, że Paweł rozumie Ducha jako materialny fenomen (s. 3). Podstawą dla takiego rozumienia jest nie tyle żydowsko-hellenistyczne podłoże (Filon; Księga Mądrości), ile materialistyczny i monistyczny stoicyzm (s. 4). Postrzega on pneumę jako gorącą i przezroczystą substancję, która konstytuuje ciała niebieskie, chroni, karmi, daje wzrost, podtrzymuje i pośredniczy w postrzeganiu świata. Pneuma, której

90 Zob. T. Engberg-Pedersen, Paul and the Stoics (Sheffield: Sheffield Academic Press 2000); T. Engberg-Pedersen, Cosmology and Self in the Apostle Paul. The Material Spirit (Oxford: Oxford University Press 2010). 
składnikiem jest ogień, odpowiada też za inteligencję. Z niej uformowana jest dusza, ona łączy w całość wszechświat, przyjmując boskie cechy (s. 19-22). Dla cnotliwego życia, według stoików, człowiek potrzebuje pneumy (s. 21). Elementy stoickiej kosmologii, są - według autora - obecne w 1 Kor 15,35-49 (s. 26-31), w szczególny sposób w Pawłowym opisie ciała niebiańskiego jako duchowego (s. 28). Paweł korzysta ze stoickiej kosmologii także w 1 Kor 15,50-55 (s. 31-37), gdzie mowa jest o przemianie rzeczywistości stworzonej, która dodatkowo miałaby nastąpić przez ogień, w wyniku konflagracji (s. 34). Odniesienie do niej Engberg-Pedersen znajduje w 1 Kor 3,12-15 i transponuje na 1 Kor 15.

W rozdziale drugim Engberg-Pedersen dostrzega materialną pneumę w innych tekstach Pawła: 1 Liście do Tesaloniczan, Liście do Galatów, 1-2 Liście do Koryntian, Liście do Filipian i Liście do Rzymian. W szczególnie interesującym nas Rz 8 autor zwraca uwagę na paralele z Flp 3,21 i 2 Kor 5,5, gdzie - według niego - pojawia się pojęcie Ducha materialnego. Posługując się kryptycznym językiem Engberg-Pedersen stwierdza, że nie ma niezaprzeczalnych dowodów na to, że Paweł rozumie tu Ducha materialnie, ale nie ma też przesłanek, które by temu przeczyły. $Z$ jednej strony autor stwierdza brak tekstualnych dowodów popierających taki tok rozumowania apostoła, z drugiej strony nie przeszkadza mu to $\mathrm{w}$ stwierdzeniu, że mamy tu $\mathrm{w}$ istocie do czynienia $\mathrm{z}$ materialnym, inspirowanym stoicyzmem Duchem (s. 51-55). Fragment Rz 8,10 Engberg-Pedersen czyta w świetle 2 Kor 4,16, twierdząc, że Paweł mówi tu o fizycznym zamieszkiwaniu Ducha w wierzących, który wypełnia życiem ich obumierające, fizyczne ciała (s. 52, 54). Z kolei w Rz 8,14-30 pojawiają się obrazy sugerujące współcierpienia ochrzczonych z Chrystusem i współuczestniczenie w Jego chwale $(8,17)$, a także posiadanie pierwszych darów Ducha $(8,23)$. We wszystkich przypadkach, według autora, należy ten język rozumieć dosłownie, a zatem objawia się tu fizyczny Duch.

Pneuma, która działa w szczególny sposób przy zmartwychwstaniu i transformacji ciała, ze względu na swój związek z fizycznością sama musi być bytem fizycznym, co widać w jej zjednoczeniu z ciałem ludzkim podkreślanym w Rz 8,11 (s. 61-62). Bóg udziela jej nieustannie jako swojej energii, która, wypełniając człowieka, oddziałuje na niego w sposób zbawczy $(8,5-10)$ (s. 71). Ostatecznie także w Rz 8,21 autor sugeruje ideę konflagracji, znaną już z 1 Kor 15, jako najlepsze podłoże dla zrozumienia, w jaki sposób Bóg wyzwoli stworzenie z niewoli zepsucia, aby mogło uczestniczyć w wolności i chwale dzieci Bożych (s. 72). Personalistyczny język, którym Paweł mówi o pneumie jako przychodzącej z pomocą $(8,16)$ i wstawiającej się za wierzącymi, w niczym nie przekreśla, według Engberg-Pedersena, stoickiej wizji materialnego, immanentnego Ducha. Apostoł w Rz 8,19-22 opisuje cały stworzony świat jako żyjący organizm, sytuując się blisko starożytnych panpsychicznych teorii na temat kosmicznej 
duszy (s. 84). Prócz oddziaływania materialnego autor tłumaczy rolę pneumy u Pawła w wymiarze kognitywnym, porównując nauczanie apostoła z Epiktetem. Duch daje człowiekowi możliwość zrozumienia Boga i opowiedzenia się po jego stronie, uwalniając go od innych wrogich mu sił i nie odbierając przy tym wolności decyzji (s. 106-138).

Zasadną krytykę poglądów Engberg-Pedersena wyraził John Levison, autor monografii The Spirit in First-Century Judaism (2002) ${ }^{91}$. W dziele tym autor w ograniczonym tylko wymiarze odnosi się do idei stoickich na temat pneumy, podając Cycerona jako ich reprezentanta (s. 70-71) i skupiając się zasadniczo na podłożu żydowskim. Analizując Filona i Józefa Flawiusza, Levison stwierdza wpływ idei platońskich i stoickich na autorów żydowskich. Używają oni związanego z filozofią słownictwa i krytycznie absorbują poglądy starożytnych na temat pneumy oraz kosmicznej więzi wszechświata (s. 145) czy przebywania Ducha w człowieku i jego związku z cnotami (s. 146-147) . $^{92}$ Ostatecznie autor, choć nie neguje wpływu idei filozoficznych na literaturę żydowską I w., proponuje jako bliższe im podłoże teksty Starego Testamentu ${ }^{93}$.

Podobne podejście dominuje w jego polemicznym artykule „Paul in the Stoa Poecile" z 2011 r., w którym odnosi się on do głównych tez Engberg-Pedersena zawartych w jego Cosmology and the Self ${ }^{94}$. Levison docenia ostrożność $\mathrm{w}$ formułowaniu tez duńskiego egzegety i próbę przezwyciężenia dychotomii między Pawłem Żydem i przedstawicielem kultury grecko-rzymskiej (s. 417). Równocześnie autor krytykuje dwa modele stoickie, na które powoływał się Engeberg-Pedersen, a które - według niego - nie mają zastosowania u Pawła: model konflagracji (1 Kor 15) oraz model natchnienia (s. 423-425). Tekst 1 Kor 15 nie mówi nic o ogniu, a dodatkowo odnawiający wszystko ogień u stoików nie wymagał przemiany jednostki i nie odnosił się do niej, lecz do duszy świata (s. 420-421). Podobnie odległe sobie są Pawłowa i stoicka idea natchnienia. U Cycerona natchnienie wiąże się z wróżbami i z wpływem substancji chemicznych czy muzyki (s. 425-426). Boski Duch, o którym mówi Cyceron, mieszka w człowieku od urodzenia do śmierci, nie przychodzi, jak w przypadku Pawła, w pewnym momencie przez objawienie. Levison ostatecznie krytykuje Engberg-Pedersena

91 Zob. J.R. Levison, The Spirit in First-Century Judaism (AGJU 29; Leiden - Boston, MA: Brill 2002).

92 Zob. także J.R. Levison, „Inspiration and the Divine Spirit in the Writings of Philo Judaeus”, JSJ 26/3 (1995) 280-308.

93 W podobnym stylu autor bada Pawłowe metafory w 1 Kor 3,16-17; 6,19; 2 Kor 6,14-7,1, odwołując się głównie do ST I Qumran, ale cytując także paralele stoickie. J.R. Levison, „The Spirit and the Temple in Paul's Letters to the Corinthians", Paul and his theology (red. S.E. Porter) (Pauline Studies 3; Leiden - Boston: Brill 2006) 189-215, zwł. 199-201, 213-214.

94 Zob. J.R. Levison, „Paul in the Stoa Poecile. A Response to Troels Engberg-Pedersen, Cosmology and Self in the Apostle Paul: The Material Spirit (Oxford, 2010)", JSNT 33/4 (2011) 415-432. 
za szukanie paraleli do Pawłowej pneumatologii w myśli stoickiej przy jednoczesnym zaniedbaniu kontekstu Starego Testamentu i Qumran, gdzie także pojawia się Duch jako byt kognitywny i przewodnik człowieka ${ }^{95}$. Skoro nawet u Filona można zaobserwować pewne napięcie i krytykę idei stoickich, tym bardziej powinny one być widoczne u Pawła, czego Engberg-Pedersen zupełnie nie uwzględnia (s. 431-432) ${ }^{96}$.

Wreszcie najbardziej systematyczną krytykę idei stoickich związanych z materialnym Duchem przeprowadził w swojej książce The Holy Spirit and Ethics in Paul (2010) Volker Rabens. Autor nie obiera sobie za cel walki z tymi, którzy dostrzegają wpływy stoickie u Pawła, lecz raczej obnaża niedostatki materialnych i mechanistycznych wizji wpływu Ducha na człowieka i jego życie etyczne. Zadaje przy tym pytanie, w jaki sposób Paweł wyobraża sobie oddziaływanie Ducha na życie moralne człowieka (s. 1). W imponującym streszczeniu wielu niemieckich i anglojęzycznych pozycji na temat Ducha i etyki, którego autor dokonuje na początku książki, brak autorów, takich jak Hoyle, Lee, Johnson Hodge, Stowers czy Levison. W zasadniczej części swego studium Rabens proponuje alternatywny wobec materialistycznego ujęcia model działania Ducha, który poprzez poznanie i pogłębioną wspólnotę z Bogiem, Chrystusem i wspólnotą uzdalnia wierzących do moralnego życia (s. 21). W części pierwszej autor bada podstawy materialistycznej koncepcji Ducha (s. 23-120), wskazując na dwie błędne zasady, na których opierają się jej orędownicy: 1) brak zdolności abstrakcyjnego pojmowania bytu jako niematerialnego wśród starożytnych (zob. jednak Platon) (s. 28-30) oraz 2) zbyt skromny związek między Duchem i etyką w literaturze starożytnej (s. 31). Prócz tego autorzy postulujący materialny, właściwy dla stoicyzmu, charakter Ducha u Pawła, od Gunkela po Engberg-Pedersena, popełniają według Rabensa błąd zbyt dosłownej interpretacji Pawłowych metafor (s. 37, 43-54).

Badając literaturę żydowską (Stary Testament, Qumran, Józef i Asenet, Filon), autor nie stwierdza w niej obecności koncepcji materialnego Ducha, uznaje natomiast związek Ducha z etyką, ale nie na zasadzie materialnej koncepcji wypełnienia człowieka (s. 25-79). W rozdziale trzecim The Holy Spirit and Ethics in Paul pojawia się kwestia materialnego Ducha u Pawła, a wraz z nią interesujące nas teksty przynależące do Rz 8. W Rz 8,9 autor interpretuje obraz zamieszkiwania Ducha w wierzących zarówno dosłownie (pozwala na bliskie zjednoczenie z Chrystusem, poddaje pod jego władzę), jak i metaforycznie (oznacza przynależność) (s. 84-86). Rabens krytykuje materialistyczne

95 Zob. Lb 11,17; Dn 5,11-12; 6,3; Hi 32,16-20; Ps 51,12; 1QH 11.19-22; 20.11-12.

96 Autor ukazuje szerzej krytyczne podejście Filona do wykorzystywanych przezeń teorii stoickich w swojej książce Levison, The Spirit in First-Century Judaism, 147-151. 
koncepcje ciała duchowego w Rz 15,44 i Rz 8,11, sugerując, że Pawłowe opisy ciała zmartwychwstałego oznaczają nie tyle jego materialną naturę, ile nowość przemienionego ciała w stosunku do ciała starego (s. 86-96). W podobny sposób chrzest nie funkcjonuje u Pawła jako wydarzenie fizycznego napełnienia Duchem, oznaczając raczej moment nawrócenia i wtajemniczenia (s. 96-119).

W drugiej części książki autor proponuje swój model relacyjny, prezentując najpierw jego ramy (s. 123-133, 138-145) i zwracając uwagę na temat relacji w teologii Pawła (s. 134-138), by potem zaaplikować go do konkretnych Pawłowych tekstów (s. 171-242). Dzięki Duchowi następuje swego rodzaju zmiana przymierzy, a wierzący uwolnieni od grzechu, śmierci i Prawa przynależą odtąd do Chrystusa, trwają „w Nim” (Rz 8,1) (s. 172). Mieszka w nich Duch Chrystusa, a wraz z Nim sam Chrystus (Rz 8,9-10). Przeciwnie do sytuacji rozdartego człowieka z Rz 7,18, wierzący doświadczają bliskości Pana, która uzdalnia ich do etycznego życia (Rz 8,7-8). Wciąż mogą oni żyć według ciała (Rz 8,12-13), a zatem wymaga się od nich wysiłku duchowego, lecz dzięki Duchowi mogą także stawać się coraz bardziej „chrystomorficzni” (Rz 8,29) (s. 172). Przemiana dokonująca się dzięki Duchowi oznacza coraz głębsze uzdolnienie do życia moralnego (s. 203).

Podobnie motywująca i uzdalniająca do etycznego postępowania jest dla wierzących relacja synowska, którą kształtuje Duch (Rz 8,14-17). Autor nie pojmuje tu roli Ducha wyłącznie jako tego, który przypomina ochrzczonym o ich nowej tożsamości. Aktywnie kształtuje On relację synowską wierzących, a ta z kolei uzdalnia ich do świętego życia (s. 204, 209-215). Rabens podkreśla nacisk, jaki Paweł kładzie na działanie Ducha w Rz 8,14-17 w stosunku do Rz 8,12-13 (s. 213-215). Duch jest tym, który tworzy bliską relację z Bogiem, urzeczywistnia adopcję wierzących i ją potwierdza (s. 216). Metafora adopcji wyraża, według autora, nową tożsamość dzieci Bożych i kochającą relację z Bogiem, która determinuje ich działanie (s. 218). Nową więź kreowaną przez Ducha charakteryzuje przede wszystkim bliskość (s. 219), która wyraża się w wołaniu „Abba”, pojawiającym się na ustach wierzących (s. 225). Duch potwierdza tę relację swoim świadectwem $(8,16)$, kwalifikując ją jako wydarzenie obiektywne i powtarzalne w życiu każdego z ochrzczonych (s. 226-227). Duch w Rz 8,12-17 działa ostatecznie na trzech poziomach: 1) umożliwia przejście od mentalności niewolników do mentalności synów i dzieci Bożych, 2) wprowadza w bliską relację z Ojcem, która daje siłę do życia moralnego i kształtuje relację z Bogiem na wzór Chrystusa, 3) pozwala odkryć aspekt wspólnotowy doświadczenia wiary (s. 228-237). 


\section{Podsumowanie cz.1: \\ krytyczna ewaluacja prac na temat obecności stoickich elementów w pneumatologii Pawła}

W jaki sposób można podsumować przedstawione powyżej różnorodne publikacje, których autorzy poruszają kwestię związku Pawłowej pneumatologii z teoriami pochodzenia stoickiego? Rozpoczynając od szkoły niemieckiej, Gunkel mimo zdecydowanego opowiedzenia się za materialnym Duchem w listach Pawła, paradoksalnie wyklucza wpływ filozofii platońskiej na apostoła, nie wspominając w ogóle o stoikach. Wynika to z jego założeń hermeneutycznych, według których zwalcza on wszelkie formy współczesnego sobie idealizmu filozoficznego, optując za dosłowną, czyli realistyczną interpretacją Pawła. Rabens słusznie obnaża słabość rozumowania jego i wielu podobnych mu komentatorów, którzy uznawali niezdolność starożytnych do myślenia na temat pneumy w kategoriach abstrakcyjnych i niematerialnych ${ }^{97}$. Choć platonizm w I w. nie był tak popularny jak inne, choćby stoickie, szkoły filozoficzne, dostarcza on jednak dowodów na pojmowanie bytów w kategoriach czysto duchowych ${ }^{98}$. Idee Gunkela pozostają także pod zbyt wyraźnym wpływem jego hermeneutyki filozoficznej.

Do lamusa historii egzegezy odeszły już także XX-wieczne teorie na temat wszechobecnej gnozy hellenistycznej inspirującej chrześcijańskich autorów, które propagował Käsemann"9. Trudno uznać jego antynomię ciało-Duch za istotną cechę różniącą Pawła od stoików, ponieważ w Rz 8 apostoł, podobnie jak stoicy, opisuje Ducha mieszkającego w ludzkim ciele i przemieniającego je. Ostatecznie Käsemann dystansuje Pawła od stoicko-gnostyckich teorii na temat Ducha, twierdząc, że apostoł posługuje się jedynie kategoriami obecnymi we wspólnocie korynckiej. Język apostoła na temat pneumy wydaje się jednak znacznie bardziej uniwersalny i trudno ograniczyć go do jednej wspólnoty czy nawet wyłącznie do środowiska grecko-rzymskiego. Levison ukazał dobrze

97 Zob. Rabens, The Holy Spirit and Ethics in Paul, 36-38, 266. Na temat Gunkela, zob. także M. Wenk, Community-Forming Power. The Socio-Ethical Role of the Spirit in Luke-Acts (London: T \& T Clark 2004) 15-21; J. Frey - J.R. Levison, „The Origins of Early Christian Pneumatology. On the Rediscovery and Reshaping of the History of Religions Quest", The Holy Spirit, Inspiration, and the Cultures of Antiquity. Multidisciplinary Perspectives (red. J. Frey - J.R. Levison) (Ekstasis 5; Berlin - Boston: De Gruyter 2014) 4-9.

98 Zob. Rabens, The Holy Spirit and Ethics in Paul, 28-30.

99 Por. E.M. Yamauchi, „Pre-Christian Gnosticism, the New Testament and Nag Hammadi in Recent Debate", Themelios 10/1 (1984) 22-27; M.A. Williams, Rethinking «Gnosticism». An Argument for Dismantling a Dubious Category (Princeton: Princeton University Press 1996); L.W. Hurtado, „Fashions, Fallacies and Future Prospects in New Testament Studies”, JSNT 36/4 (2014) 303-307. 
zbieżność spojrzenia na pneumę, którą odnajdujemy w tekstach hellenistycznych i żydowskich ${ }^{100}$.

Pozostając wciąż w kręgu badaczy języka niemieckiego, Stalder używa dla określenia natury Ducha anachronicznych w stosunku do Pawła kategorii osoby czy też filozoficznego pojęcia bytu ${ }^{101}$. Opisanie jego zamieszkiwania w człowieku jako nieredukowalnego i niewytłumaczalnego cudu ma pewną zaletę o tyle, o ile podkreśla aspekt daru i łaski, z drugiej jednak strony w żaden sposób nie przyczynia się do zrozumienia Jego działania w człowieku. Opis funkcjonowania Ducha autorstwa Staldera jest mocno redukcjonistyczny, sprowadzając Go zasadniczo do elementu kognitywnego ${ }^{102}$. Znacznie bardzie zniuansowane i lepiej oparte egzegetycznie są analizy Horna, choć powtarza on za Käsemannem poglądy na temat korynckich korzeni Pawłowej sakramentologii i materialnego Ducha. Horn wprowadza rozróżnienie formy substancjalnej, czyli praktycznie osobowej, którą Duch przyjmuje, zamieszkując w wierzącym, i jego materialnego charakteru, kiedy łączy się np. z wodą chrztu. W pierwszym przypadku korzysta z kategorii tomistycznych, w drugim - z materialnej koncepcji Ducha właściwej stoikom i tekstom medycznym. Naraża się tu na zarzut anachroniczności czy też używania pojęć niemających związku z myślą i kontekstem historycznym Pawła. W drugim przypadku można zgodzić się z Rabensem twierdzącym, że zasadniczą słabością Horna i innych podobnych mu autorów jest zbyt dosłowne czytanie Pawłowych metafor. Wydaje się także, że odłączenie Ducha od etyki, które proponuje Horn, i sprowadzenie Go jedynie do roli Tego, który przygotowuje i umożliwia miłość bliźniego, nie czyni zadość bogactwu darów, którymi opisuje się Jego działanie u Pawła ${ }^{103}$.

Przechodząc do badaczy obszaru amerykańsko-brytyjskiego, godne polecenia i znacznie bardziej wyważone podejście do myśli Pawła prezentuje praca Hoyle'a z początku XX w. Dopatruje się on podobieństw między stoikami i apostołem głównie w sferze teorii poznania oraz pewnych popularnych koncepcji

100 Zob. Levison, The Spirit in First-Century Judaism, 83-161.

101 Zob. także szczegółowe omówienie i krytykę jego dzieła w Rabens, The Holy Spirit and Ethics in Paul, 282-288.

102 Podobny kognitywny aspekt chrztu i działania Ducha akcentuje Siikavirta, który umieszcza Rz 6-8 w kontekście stoickiej teorii poznania i etyki. Zob. S. Siikavirta, Baptism and Cognition in Romans 6-8. Paul's Ethics beyond ,Indicative" and "Imperative” (WUNT II/407; Tübingen: Mohr Siebeck 2015) 68-85.

103 Rabens słusznie zwraca uwagę na fakt, że Horn przeczy temu, co napisał na temat działania Ducha w swojej książce, Das Angeld des Geistes, gdzie opisuje Go jako sprawcę uświęcenia (s. 385-389) oraz przemiany wierzących (s. 422-428). Zob. Rabens, The Holy Spirit and Ethics in Paul, 297-298. Więcej na temat prezentacji i krytyki poglądów Horna zob. Rabens, The Holy Spirit and Ethics in Paul, 12-14, 295-299; V. Rabens, ,The Development of Pauline Pneumat tology. A Response to F.W. Horn”, BZ 43 (1999) 161-179; R. Penna, „F. Horn, Das Angeld des Geistes: Studien zur paulinischen Pneumatologie (Göttingen: Vandenhoeck et Ruprecht 1992)", Bib 75/2 (1994) 287-291. 
i języka, z których apostoł korzystał, aby dotrzeć do swych słuchaczy. Paweł używa ich w sposób krytyczny, oczyszczając interesujące nas pojęcie pneumy ze stoickich znamion immanencji i materializmu. Nawiązuje do popularnych hellenistycznych idei, czyniąc z nich punkt wyjścia dla głoszonej przez siebie Ewangelii. Monografia Hoyle'a zupełnie niesłusznie pozostaje dziś relatywnie mało wykorzystywanym dziełem, stanowiąc bogatą w treść i oryginalną publikację. W przeciwieństwie do niej The Corinthian Body Martina stanowiło i wciąż stanowi punkt odniesienia dla wielu innych monografii, opracowań interdyscyplinarnych, naukowych, popularnych i encyklopedycznych ${ }^{104}$. Podobnie jak Hoyle, Martin ogranicza wpływy stoickie u Pawła do wizji świata, którą apostoł przyjmuje nie tyle jako swoją, ile jako nośnik swojej Ewangelii w Koryncie. To podejście wydaje się nieco przepracowaną wersją korynckiego pochodzenia koncepcji materialnej pneumy u Pawła, którą widzieliśmy już u Käsemanna. Martin stwierdza ostatecznie, że Paweł nie jest filozofem, lecz apokaliptykiem, objawiając swoje modernistyczne, oparte na krytykowanym przez Engberg-Pedersena dualizmie, podejście do Pawła ${ }^{105}$.

Dalej u Lee dominuje niemal bezkrytyczne podejście do teorii stoickich w 1 Kor 12-14. Podobnie kwestie te traktuje Troy Martin, który, choć stwierdza różnice między Pawłem i starożytnymi tekstami medycznymi, nie akcentuje ich, skupiając się wyłącznie na podobieństwach. Materialistyczna wizja Ducha dostającego się do organizmu przez uszy, pory w skórze czy żołądek tchnie zbyt dosłownym odczytaniem Pawłowych metafor. Trudno uwierzyć, aby Pawła interesował ten właśnie aspekt obecności Ducha w człowieku ${ }^{106}$. Pozostając w tym samym nurcie biologicznych koncepcji pneumy, Johnson Hodge oraz Stowers odnoszą się w swoich publikacjach do teorii krasis i prezentują interesujący aspekt przebywania Ducha w człowieku, który nie znosi ludzkiej odrębności. Także u tych autorów brak jednak krytycznego podejścia do wykorzystywanych przez nich teorii filozoficznych i medycznych, dominuje natomiast materialistyczne odczytanie obecności Ducha w wierzących. Stowers zbyt łatwo przechodzi od Pawłowego uczestniczenia w kulturze hellenistycznej i używania

104 Skromne odniesienia do Hoyle'a można znaleźć m.in. w: Thiselton, The Holy Spirit - in Biblical Teaching, through the Centuries, and Today 31-32, 76, 78; A.C. Thiselton, „The Holy Spirit in 1 Corinthians. Exgesis and Reception History in the Patristic Era", The Holy Spirit and Christian Origins. Essays in Honor of James D.G. Dunn (red. J.D.G. Dunn - G. Stanton - B.W. Longenecker - S.C. Barton) (Grand Rapids, MI: Eerdmans 2004) 218; F. Philip, The Origins of Pauline Pneumatology. The Eschatological Bestowal of the Spirit upon Gentiles in Judaism and in the Early Development of Paul's Theology (WUNT II/ 194; Tübingen: Mohr Siebeck 2005) 127; E. Konsmo, The Pauline Metaphors of the Holy Spirit. The Intangible Spirit's Tangible Presence in the Life of the Christian (StBibLit 130; New York: Peter Lang 2010) 70-71.

105 Zob. Engberg-Pedersen, Cosmology and Self in the Apostle Paul, 17.

106 Ewaluację jego poglądów można znaleźć w Rabens, The Holy Spirit and Ethics in Paul, 99-101. 
jej pojęć do przyjmowania przez apostoła ich zawartości i treści. Wraca także do Gunkelowskich tez na temat realizmu Pawła, który stanowi fundament jego materialistycznej wizji pneumy.

Wreszcie prawdziwą apoteozę wpływów stoickich u Pawła znajdujemy u Engberg-Pedersena. Choć autor optuje za podwójnym, metaforycznym i dosłownym/materialistycznym odczytaniem Ducha u Pawła, drugie podejście zdecydowanie dominuje w jego ujęciu. Nacisk na realizm, nie idealizm, Pawła znów wydaje się mieć swoje korzenie u Gunkela, choć prowadzi do zgoła odmiennego stwierdzenia: wizja Pawłowa wprost wiąże się z popularną kosmologią stoicką. Sposób, w jaki autor dowodzi swej tezy, łącząc ze sobą różne teksty Pawłowe z 1-2 Listu do Koryntian, Listu do Filipian i Rzymian, może budzić wątpliwości. Wydaje się on zwracać większą uwagę na pojedyncze pojęcia, niż na kontekst argumentacji apostoła i charakteryzuje się cyrkularnością: jeden tekst zakwalifikowany przez autora jako stoicki służy udowadnianiu filozoficznych koncepcji w innych tekstach, które z kolei wzmacniają pogląd na temat filozoficznego charakteru tekstu wyjściowego. Dla przykładu odnalezienie idei konflagracji w 1 Kor 15 wymaga odniesienia do 1 Kor 3,12-15, po czym autor w sposób płynny aplikuje ją do Rz 8,29, konkludując, że całe stworzenie zostanie ostatecznie przemienione przez ogień. Levison słusznie krytykował wątłą bazę egzegetyczną, na której Engberg-Pedersen buduje swoją argumentację, do czego dodać można brak dbałości o kontekst i różnice między analizowanymi fragmentami ${ }^{107}$. Realizm doświadczeń wierzących przekłada się u autora na materializm Ducha, a jego zamieszkiwanie w ciele i udział w jego wskrzeszeniu wystarcza, aby uznać jego substancjalny charakter. Paweł u Engberg-Pedersena staje się bliski nie tylko stoickiej immanencji i materialistycznemu monizmowi, ale także panpsychicznym teoriom na temat kosmicznej duszy świata.

Zdecydowanie najlepiej pod względem egzegezy i dbałości o kontekst tekstów Pawłowych prezentują się analizy Rabensa. Jego hipoteza Ducha wprowadzającego w relację z Ojcem, Chrystusem i wierzącymi i w ten sposób uzdalniającego do życia etycznego ma solidne oparcie w tekstach biblijnych. Nie jest także zarażona anachronicznymi wpływami filozoficznymi czy też agendą ideologiczną autora. Rzetelnie punktuje on słabości innych teorii, jak brak zdolności do wysokiego stopnia abstrakcji u starożytnych czy też zbyt dosłowną interpretację Pawłowych metafor. W swoich analizach łączy on dosłowne i metaforyczne podejście do kwestii zamieszkiwania Ducha w człowieku czy też adopcji wierzących, choć dosłowność nigdy nie oznacza wizji materialistycznej i nie odpowiada na pytanie,

107 Zob. Levison, „Paul in the Stoa Poecile”, 420-421. Podobne krytyczny wobec egzegezy Engberga-Pedersena i podobieństw między stoikami a Pawłem jest J.M.G. Barclay, „Stoic Physics and the Christ-Event. A Review of Troels Engberg-Pedersen, Cosmology and the Self in the Apostle Paul. The Material Spirit", JSNT 33/4 (2011) 406-414. 
„jak” działa Duch. Rabens ucieka od dyskusji na temat natury i sposobu działania Ducha, skupiając się raczej na jego celu i owocach. W tej kwestii uprawia postulowaną przez Gunkela „fenomenologię” Ducha.

Praca Rabensa, choć ze wszech miar godna pochwały ze względu na rzetelność prowadzonych analiz i imponującą, interdyscyplinarną bibliografię, pozostawia $\mathrm{w}$ tym względzie niedosyt ${ }^{108}$. W istocie poza krytykowanymi przez autora materialistycznymi wizjami Ducha nie podejmuje się tam dogłębnej dyskusji nad innymi tematami łączącymi Pawła ze światem grecko-rzymskim, jak kognitywny, unifikujący i życiodajny charakter Ducha. Autor wydaje się także zbyt asekurancki, argumentując za marginalnym powiązaniem pneumy jako takiej z życiem etycznym ${ }^{109}$. Fakt, że Duch posiada właściwości kognitywne i umożliwia właściwe postrzeganie rzeczywistości, sugeruje już jego wpływ także na życie moralne człowieka. Wydaje się też, że bardzo interesującą perspektywę na zamieszkiwanie Ducha w człowieku daje zupełnie pomijana przez Rabensa stoicka teoria krasis. Wracając do niedocenionego dzieła Hoyle’a, autor zawarł w nim cenną sugestię dotyczącą Pawła, który z jednej strony korzysta z grecko-rzymskich pojęć, z drugiej zaś - oczyszcza je z elementów obcej sobie wizji Boga i świata. Podejście to stanie się drogowskazem dla naszych analiz prowadzonych w drugiej części niniejszego artykułu. Przyjrzymy się w nich podstawowym ideom stoickim na temat pneumy i temu, jaką perspektywę tworzą one dla analizy Rz 8. Postaramy się wydobyć na światło dzienne nie tylko podobieństwa między Pawłem i stoikami, lecz także różnice, które decydować mogą o oryginalnym ujęciu Ducha u apostoła.

\section{Bibliografia}

Achtemeier, P.J., Romans (Interpretation; Atlanta: John Knox Press 1985).

Aletti, J.-N., God's Justice in Romans. Keys for Interpretating the Epistle to the Romans (SubBi 37; Rome: Gregorian \& Biblical Press 2010).

Aletti, J.-N., „Romans 5-8. The Arrangement and Its Theological Relevance”, New Approaches for Interpreting the Letters of Saint Paul. Collected Essays : Rhetoric, Soteriology, Christology and Ecclesiology (SubBi 43; Roma: Gregorian \& Biblical Press 2012) 61-78.

108 Zob. recenzje wskazujące na nikłe odniesienia do paraleli stoickich, zbyt binarne potraktowanie problemu Ducha (materialny/niematerialny) oraz mało zróżnicowaną aplikację modelu relacyjnego u Rabensa: A.T. Wright, „V. Rabens, The Holy Spirit and Ethics in Paul. Transformation and Empowering for Religious-Ethical Life (WUNT II/283; Tübingen: Mohr Siebeck 2010)", JSJ 44/1 (2013) 117-118; F. Young, „V. Rabens, The Holy Spirit and Ethics in Paul. Transformation and Empowering for Religious-Ethical Life (WUNT II/283; Tübingen: Mohr Siebeck 2010)", JTS 66/2 (2015) 785-787.

109 Zob. Rabens, The Holy Spirit and Ethics in Paul, 31-32. 
Aletti, J.-N., „Romans 7:7-25 and Galatians 5:17. Questions and Proposals”, New Approaches for Interpreting the Letters of Saint Paul. Collected Essays: Rhetoric, Soteriology, Christology and Ecclesiology (SubBi 43; Roma: Gregorian \& Biblical Press 2012) 79-109.

Aletti, J.-N., „Romans 8. The Incarnation and Its Redemptive Impact”, New Approaches for Interpreting the Letters of Saint Paul. Collected Essays: Rhetoric, Soteriology, Christology and Ecclesiology (SubBi 43; Roma: Gregorian \& Biblical Press 2012) 111-138.

Barclay, J.M.G., „Stoic Physics and the Christ-Event. A Review of Troels Engberg-Pedersen, Cosmology and the Self in the Apostle Paul. The Material Spirit", Journal for the Study of the New Testament 33/4 (2011) 406-414.

Barrett, C.K., The Epistle to the Romans (BNTC 6; London: Hendrickson ${ }^{2} 1991$ ).

Belli, F., „Un'allusione a Is 50,8-9 in Rm 8,31-34”, Rivista Biblica Italiana 50 (2002) 153-184.

Braaten, L.J., „The Groaning Creation. The Biblical Background for Romans 8:22”, Biblical Research 50 (2005) 19-39.

Breytenbach, C., „Creation and the revelation of God's children. Liberation of enslaved bodies”, In die Skriflig 47/2 (2013) 1-7.

Byrne, B., Romans (Sacra Pagina Series 6; Collegeville, MN: Liturgical Press 1996).

Cranfield, C.E.B., A Critical and Exegetical Commentary on the Epistle to the Romans. Introduction and Commentary on Romans I-VIII (ICC; Edinburgh: T \& T Clark 2004).

Dahl, N.A., Studies in Paul. Theology for the Early Christian Mission (Minneapolis: Augsburg 1977).

Dillon, R.J., „The Spirit as Taskmaster and Troublemaker in Romans 8”, Catholic Biblical Quarterly 60/4 (1998) 682-702.

Dunn, J.D.G., Baptism in the Holy Spirit. A Re-Examination of the New Testament Teaching on the Gift of the Spirit in Relation to Pentecostalism Today (Philadelphia: Westminster Press 1970).

Dunn, J.D.G., Jesus and the Spirit. A Study of the Religious and Charismatic Experience of Jesus and the First Christians as Reflected in the New Testament (New Testament Library; London: S.C.M. Press 1975).

Dunn, J.D.G., Romans 1-8 (WBC 38A; Dallas, TX: Word Books 1988).

Elliott, N., The Rhetoric of Romans. Augmentative Constraint and Strategy and Paul's Dialogue with Judaism (JSNTSup 45; Sheffield: Sheffield Academic Press 1990).

Engberg-Pedersen, T., Paul and the Stoics (Sheffield: Sheffield Academic Press 2000).

Engberg-Pedersen, T., „The Material Spirit. Cosmology and Ethics in Paul”, New Testament Studies 55/2 (2009) 179-197.

Engberg-Pedersen, T., Cosmology and Self in the Apostle Paul. The Material Spirit (Oxford: Oxford University Press 2010).

Fitzmyer, J.A., Romans. A New Translation with Introduction and Commentary (AB 33; New York: Doubleday 1993).

Frey, J. - Levison, J.R., „The Origins of Early Christian Pneumatology. On the Rediscovery and Reshaping of the History of Religions Quest", The Holy Spirit, Inspiration, and the Cultures of Antiquity. Multidisciplinary Perspectives (red. J. Frey - J.R. Levison) (Ekstasis 5; Berlin - Boston: De Gruyter 2014) 1-37.

Friedländer, L., Darstellungen aus der sittengeschichte Roms in der Zeit von August bis zum Ausgang der Antonine (Leipzig ${ }^{5} 1881$ ).

Gieniusz, A., Romans 8,18-30. Suffering Does Not Thwart the Future Glory (USFSJH 9; Atlanta, GA: Scholars 1999).

Gieniusz, A., „«Debtors to the Spirit» in Romans 8.12? Reasons for the Silence”, New Testament Studies 59/1 (2013) 61-72. 
Godet, F.L., Commentary on Romans (Grand Rapids, MI: Kregel 1977).

Grappe, C., „Qui me délivrera de ce corps de mort? l'esprit de vie! Romains 7,24 et 8,2 comme éléments de typologie adamique", Biblica 83/4 (2002) 472-492.

Gunkel, H., Die Wirkungen des heiligen Geistes nach der populären Anschauungen der apostolischen Zeit und der Lehre des Apostels Paulus (Göttingen: Vandenhoeck \& Ruprecht 1888).

Gunkel, H., The Influence of the Holy Spirit. Popular View of the Apostolic Age and the Teaching of the Apostle Paul. Translated by Roy A. Harrisville and Philip A. Quanbeck II (Minneapolis, MN: Fortress Press 2008).

Hendriksen, W., Romans. Exposition of Paul's Epistle to the Romans (New Testament Commentary; Grand Rapids: Baker Book House 1981).

Horn, F.W., Das Angeld des Geistes. Studien zur paulinischen Pneumatologie (Göttingen: Vandenhoeck et Ruprecht 1992).

Horn, F.W., „Holy Spirit”, The Anchor Yale Bible Dictionary (red. D.N. Freedman - G.A. Herion - D.F. Graf - J.D. Pleins - A.B. Beck) (New York: Doubleday 1992) 260-280.

Horn, F.W., „Wandel im Geist. Zur pneumatologischen Begründung der Ethik bei Paulus”, Kirche und Dogma 38/2 (1992) 149-170.

Hoyle, R.B., The Holy Spirit in St. Paul (London: Hodder and Stoughton 1927).

Hurtado, L.W., „Fashions, Fallacies and Future Prospects in New Testament Studies”, Journal for the Study of the New Testament 36/4 (2014) 299-324.

Jaquette, J.L., „Life and Death, Adiaphora, and Paul's Rhetorical Strategies”, Novum Testamentum 38/1 (1996) 30-54.

Jewett, R., „Impeaching God's Elect. Roman 8,33-37 in Its Rhetorical Situation”, Paul, Luke and the Graeco-Roman world. Essays in honour of Alexander J.M. Wedderburn (red. A.J.M. Wedderburn - A. Christophersen) (JSNTSup 217; London - New York: T \& T Clark 2003) 37-58.

Jewett, R. - Kotansky, R.D., Romans. A Commentary on the Book of Romans (Hermeneia; Minneapolis: Fortress Press 2007).

Johnson Hodge, C., If Sons, then Heirs. A Study of Kinship and Ethnicity in the Letters of Paul (Oxford - New York: Oxford University Press 2007).

Käsemann, E., Leib und Leib Christi. Eine Untersuchung zur paulinischen Begrifflichkeit (BHT 9; Tübingen: Mohr Siebeck 1933).

Käsemann, E., „The Pauline Doctrine of the Lord's Supper”, Essays on New Testament themes (SBT 41; London: SCM Press 1964) 108-135.

Käsemann, E., Commentary on Romans (London: SCM Press 1980).

Klauck, H.-J., Herrenmahl und hellenistischer Kult. Eine religionsgeschichtliche Untersuchung zum ersten Korintherbrief (NTAbh 15; Münster: Aschendorff 1982).

Konsmo, E., The Pauline Metaphors of the Holy Spirit. The Intangible Spirit's Tangible Presence in the Life of the Christian (StBibLit 130; New York: Peter Lang 2010).

Kowalski, M., „Problem Bożej sprawiedliwości w świetle Listu do Rzymian”, Verbum Vitae 26 (2014) 95-126.

Kowalski, M., „Bóg ustanowił Chrystusa nowym miejscem przebłagania. Pawłowa wizja usprawiedliwienia według Rz 3,25-26”, Głoszenie odpuszczenia grzechów w imię Jezusa (Łk 24,47) (red. K. Mielcarek) (Lublin: Wydawnictwo KUL 2015) 163-190.

Kowalski, M., „Nowe życie jak ziarno gorczycy. Spójność argumentacji retorycznej Pawła w Rz 5 - 8”, The Biblical Annals 7/4 (2017) 459-485.

Kowalski, M., „Apokaliptyczny gniew Boga i jego miejsce w Ewangelii Pawła (Rz 1,18-32)”, Verbum Vitae 33 (2018) 203-249. 
Kowalski, M., „God the Benefactor and His Human Clients in Rom. 5-8”, The Biblical Annals 8/1 (2018) 47-69.

Kowalski, M., „The Brokerage of the Spirit in Rom 8”, Catholic Biblical Quarterly (2018).

Kuss, O., Der Römerbrief (Regensburg: Pustet 1963-1978).

la Potterie, I.de, „Le chrétien conduit par l'Esprit dans son cheminement eschatologique (Rom 8,14)", The Law of the Spirit in Rom 7 and 8 (red. J.-M. Cambier - B. Langley) (Rome: St Paul's Abbey 1976) 209-278.

Lee, J.H., Paul's Gospel in Romans. A Discourse Analysis of Rom. 1:16-8:39 (Linguistic Biblical Studies 3; Leiden - Boston: Brill 2010).

Lee, M.V., Paul, the Stoics, and the Body of Christ (SNTSMS 137; Cambridge: Cambridge University Press 2006).

Levison, J.R., „Inspiration and the Divine Spirit in the Writings of Philo Judaeus”, Journal for the Study of Judaism in the Persian, Hellenistic, and Roman Periods 26/3 (1995) 271-323.

Levison, J.R., The Spirit in First-Century Judaism (AGJU 29; Leiden - Boston, MA: Brill 2002).

Levison, J.R., „The Spirit and the Temple in Paul's Letters to the Corinthians”, Paul and his theology (red. S.E. Porter) (Pauline Studies 3; Leiden - Boston: Brill 2006) 189-215.

Levison, J.R., „Paul in the Stoa Poecile. A Response to Troels Engberg-Pedersen, Cosmology and Self in the Apostle Paul: The Material Spirit (Oxford, 2010)", Journal for the Study of the New Testament 33/4 (2011) 415-432.

Lohse, E., „Zur Analyse und Interpretation von Röm 8,1-17”, The Law of the Spirit in Rom 7 and 8 (red. J.-M. Cambier - B. Langley) (Rome: St Paul's Abbey 1976) 129-146.

Luz, U., „Zum Aufbau von Röm 1-8”, Theologische Zeitschrift 25 (1969) 161-181.

Martin, D.B., The Corinthian Body (New Haven: Yale University Press 1995).

Martin, T.W., „Paul's Pneumatological Statements and Ancient Medical Texts”, The New Testament and Early Christian Literature in Greco-Roman Context. Studies in Honor of David E. Aune (red. D.E. Aune - J. Fotopoulos) (NovTSup 122; Leiden - Boston: Brill 2006) 105-126.

Matand Bulembat, J.-B., Noyau et enjeux de l'eschatologie paulinienne. De l'apocalyptique juive et de l'eschatologie hellénistique dans quelques argumentations de l'apôtre Paul. Étude rhétorico-exégétique de 1 Co 15, 35-58; 2 Co 5, 1-10 et Rm 8, 18-30 (WUNT II/ 84; Berlin - New York: De Gruyter 1997).

McDonald, P.M., „Romans 5:1-11 as a Rhetorical Bridge”, Journal for the Study of the New Testament 40 (1990) 81-96.

Moo, D.J., The Epistle to the Romans (NICNT; Grand Rapids, MI: Eerdmans 1996).

Morris, L., The Epistle to the Romans (The Pillar New Testament Commentary; Leicester, England - Grand Rapids, MI: Apollos; Eerdmans 1988).

Mounce, R.H., Romans (NAC 27; Nashville, TN: Broadman \& Holman 1995).

Murray, J., The Epistle to the Romans (NICNT; Grand Rapids, MI: Eerdmans 1959, 1965).

Myers, C.D., „Chiastic Inversion in the Argument of Romans 3-8”, Novum Testamentum 35/1 (1993) 30-47.

Penna, R., „F. Horn, Das Angeld des Geistes: Studien zur paulinischen Pneumatologie (Göttingen: Vandenhoeck et Ruprecht 1992)", Biblica 75/2 (1994) 287-291.

Philip, F., The Origins of Pauline Pneumatology. The Eschatological Bestowal of the Spirit upon Gentiles in Judaism and in the Early Development of Paul's Theology (WUNT II/ 194; Tübingen: Mohr Siebeck 2005).

Pitta, A., „Form and Content of the Propositio in Pauline Letters: the Case of Rom 5.1-8.39”, Revue Biblique 122/4 (2015) 575-591. 
Rabens, V., „The Development of Pauline Pneumatology. A Response to F.W. Horn”, Biblische Zeitschrift 43 (1999) 161-179.

Rabens, V., The Holy Spirit and Ethics in Paul. Transformation and Empowering for Religious-Ethical Life (WUNT II/283; Tübingen: Mohr Siebeck 2010).

Sanday, W. - Headlam, A.C., A critical and Exegetical Commentary on the Epistle of the Romans (ICC; New York 1897).

Sandmel, S., „Parallelomania”, Journal of Biblical Literature 81/1 (1962) 1-13.

Schille, G., „Die Liebe Gottes in Christus. Beobachtungen zu Rm 8,31-39”, Zeitschrift für die neutestamentliche Wissenschaft und die Kunde der älteren Kirche 59 (1968) 230-244.

Schreiner, T.R., Romans (BECNT 6; Grand Rapids, MI: Baker Books 1998).

Siikavirta, S., Baptism and Cognition in Romans 6-8. Paul's Ethics beyond 'Indicative' and 'Imperative' (WUNT II/407; Tübingen: Mohr Siebeck 2015).

Snyman, A.H., „Style and the Rhetorical Situation of Romans 8. 31-39”, New Testament Studies 34 (1988) 218-231.

Stalder, K., Das Werk des Geistes in der Heiligung bei Paulus (Zürich: EVZ-Verlag 1962).

Stowers, S.K., „What Is «Pauline Participation in Christ»?”, Redefining First-Century Jewish and Christian Identities. Essays in Honor of Ed Parish Sanders (red. F.E. Udoh - S. Heschel M.A. Chancey - G. Tatum) (Christianity and Judaism in Antiquity Series 16; Notre Dame, IN: University of Notre Dame Press 2008) 352-371.

Stuhlmacher, P., Gerechtigkeit Gottes bei Paulus (FRLANT 87; Göttingen: Vandenhoeck \& Ruprecht 1965).

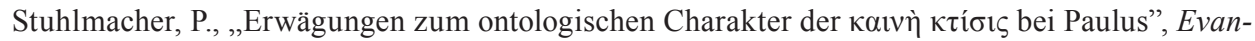
gelische Theologie 27/1 (1967) 1-35.

Talbert, C.H., „Tracing Paul's train of thought in Romans 6-8”, Review and Expositor 100/1 (2003) 53-63.

Thiselton, A.C., „The Holy Spirit in 1 Corinthians. Exgesis and Reception History in the Patristic Era”, The Holy Spirit and Christian Origins. Essays in Honor of James D.G. Dunn (red. J.D.G. Dunn - G. Stanton - B.W. Longenecker - S.C. Barton) (Grand Rapids, MI: Eerdmans 2004) 207-228.

Thiselton, A.C., The Holy Spirit-- in Biblical Teaching, through the Centuries, and Today (Grand Rapids, MI: Eerdmans 2013).

van Rensburg, J.J.J., „The Children of God in Romans 8”, Neotestamentica 15 (1981) 139-179.

Wasserman, E., „Paul among the Philosophers. The Case of Sin in Romans 6-8”, Journal for the Study of the New Testament 30/4 (2008) 387-415.

Wenk, M., Community-Forming Power. The Socio-Ethical Role of the Spirit in Luke-Acts (London: $\mathrm{T} \& \mathrm{~T}$ Clark 2004).

Wilckens, U., Der Brief an die Römer (EKKNT; Neukirchen-Vluyn - Zurich: Neukirchener Verlag; Benziger 1978-1981).

Williams, M.A., Rethinking «Gnosticism». An Argument for Dismantling a Dubious Category (Princeton: Princeton University Press 1996).

Witherington, B. - Hyatt, D., Paul's Letter to the Romans. A Socio-Rhetorical Commentary (Grand Rapids, MI: Eerdmans 2004).

Wolter, M., Rechtfertigung und zukünftiges Heil. Untersuchungen zu Röm 5,1-11 (BZNW 43; Berlin - New York: De Gruyter 1978).

Wright, A.T., „V. Rabens, The Holy Spirit and Ethics in Paul. Transformation and Empowering for Religious-Ethical Life (WUNT II/283; Tübingen: Mohr Siebeck 2010)", Journal for the Study of Judaism in the Persian, Hellenistic, and Roman Periods 44/1 (2013) 117-118. 
Yamauchi, E.M., „Pre-Christian Gnosticism, the New Testament and Nag Hammadi in Recent Debate", Themelios 10/1 (1984) 22-27.

Young, F., „V. Rabens, The Holy Spirit and Ethics in Paul. Transformation and Empowering for Religious-Ethical Life (WUNT II/283; Tübingen: Mohr Siebeck 2010)", Journal of Theological Studies 66/2 (2015) 785-787. 